\section{OPEN ACCESS}

Edited by:

William C. Burns,

American University, United States

Reviewed by:

Phillip Williamson,

University of East Anglia,

United Kingdom

Charithea Charalambous,

Heriot-Watt University,

United Kingdom

*Correspondence:

Felix Schenuit

felix.schenuit@uni-hamburg.de

Specialty section:

This article was submitted to

Negative Emission Technologies,

a section of the journal

Frontiers in Climate

Received: 07 December 2020

Accepted: 02 February 2021

Published: 04 March 2021

Citation:

Schenuit F, Colvin R, Fridahl M, McMullin $B$, Reisinger $A$, Sanchez $D L$,

Smith SM, Torvanger A, Wreford A and Geden O (2021) Carbon Dioxide

Removal Policy in the Making: Assessing Developments in 9 OECD

Cases. Front. Clim. 3:638805

doi: 10.3389/fclim.2021.638805

\title{
Carbon Dioxide Removal Policy in the Making: Assessing Developments in 9 OECD Cases
}

\begin{abstract}
Felix Schenuit ${ }^{1,2 *}$, Rebecca Colvin ${ }^{3}$, Mathias Fridahl ${ }^{4}$, Barry McMullin ${ }^{5}$, Andy Reisinger ${ }^{6}$, Daniel L. Sanchez ${ }^{7}$, Stephen M. Smith ${ }^{8}$, Asbjørn Torvanger ${ }^{9}$, Anita Wreford ${ }^{10}$ and Oliver Geden ${ }^{2}$

${ }^{1}$ Center for Sustainable Society Research, University of Hamburg, Hamburg, Germany, ${ }^{2}$ German Institute for International and Security Affairs (SWP), Berlin, Germany, ${ }^{3}$ Crawford School of Public Policy, Australian National University, Canberra, ACT, Australia, ${ }^{4}$ Department of Thematic Studies, Environmental Change, Centre for Climate Science and Policy Research, Linköping University, Linköping, Sweden, ${ }^{5}$ Dublin City University, Dublin, Ireland, ${ }^{6}$ Ministry for the Environment, Wellington, New Zealand, ' Department of Environmental Science, Policy, and Management (ESPM), University of California, Berkeley, Berkeley, CA, United States, ${ }^{8}$ Smith School of Enterprise and the Environment, Oxford University, Oxford, United Kingdom, ${ }^{9}$ Center for International Climate Research (CICERO), Oslo, Norway, ${ }^{10}$ Agribusiness and Economics Research Unit (AERU), Lincoln University, Christchurch, New Zealand
\end{abstract}

Since the adoption of the Paris Agreement in 2015, spurred by the 2018 IPCC Special Report on Global Warming of $1.5^{\circ} \mathrm{C}$, net zero emission targets have emerged as a new organizing principle of climate policy. In this context, climate policymakers and stakeholders have been shifting their attention to carbon dioxide removal (CDR) as an inevitable component of net zero targets. The importance of CDR would increase further if countries and other entities set net-negative emissions targets. The scientific literature on CDR governance and policy is still rather scarce, with empirical case studies and comparisons largely missing. Based on an analytical framework that draws on the multi-level perspective of sociotechnical transitions as well as existing work on CDR governance, we gathered and assessed empirical material until early 2021 from 9 Organization for Economic Co-operation and Development (OECD) cases: the European Union and three of its Member States (Ireland, Germany, and Sweden), Norway, the United Kingdom, Australia, New Zealand, and the United States. Based on a synthesis of differences and commonalities, we propose a tripartite conceptual typology of the varieties of CDR policymaking: (1) incremental modification of existing national policy mixes, (2) early integration of CDR policy that treats emission reductions and removals as fungible, and (3) proactive CDR policy entrepreneurship with support for niche development. Although these types do not necessarily cover all dimensions relevant for CDR policy and are based on a limited set of cases, the conceptual typology might spur future comparative work as well as more fine-grained case-studies on established and emerging CDR policies.

Keywords: carbon dioxide removal, net zero, climate policy, case studies, typology, socio-technical transitions, OECD 


\section{INTRODUCTION}

Since the adoption of the Paris Agreement and the publication of the IPCC's Special Report on Global Warming of $1.5^{\circ} \mathrm{C}$ (SR1.5), numerous political actors have agreed on net zero emissions targets. This type of long-term target-usually, but not always, defined as a balance of greenhouse gas (GHG) emissions and removals-is emerging as a new organizing principle of climate policy at almost all political levels. Attempts to operationalize net zero targets have been accompanied by increasing attention on the need for anthropogenic carbon dioxide removal ${ }^{1}$ (CDR) to achieve these targets (Geden, 2016a; Fuss et al., 2020). The importance of CDR would increase further if pathways involving net-negative emissions are pursued in order to recover carbon budgets consistent with temperature goals after they are exceeded (IPCC, 2018).

The scarce but growing academic literature on the governance of CDR has shown that the configuration and design of CDR policies, as well as their interactions with other climate policies, have important implications for the role of CDR in the transition toward net zero emissions societies (Bellamy et al., 2019; McLaren et al., 2019; Geden and Schenuit, 2020). Based on a comparison of nine case studies, this article attempts to track the extent to which CDR policies are already part of domestic climate policy regimes and how the integration of CDR is evolving. While the transition of international climate governance toward a bottom-up, polycentric, and performative climate governance unfolds (Aykut et al., 2020), analyzing the facts on the ground of transformations toward deep decarbonization becomes even more important (Victor et al., 2019).

In the process of case selection, we followed four key criteria: (1) We limit our cases to members of the Organization for Economic Co-operation and Development (OECD). Countries with high income and high historical emissions are generally expected to be responsible for a greater quantity of CDR deployment if distributional equity is taken into account (Fyson et al., 2020; Pozo et al., 2020). This reflects the expectations institutionalized in the international climate negotiations under the United Nations Framework Convention on Climte Change (UNFCCC). Although the Paris Agreement does not officially maintain the dichotomy of Annex 1 and non-Annex 1 countries and has introduced a less rigid distinction between developed and developing countries as well as other subtle differentiations (Pauw et al., 2019), aggregate expectations for high-income countries with historically high emissions to lead on climate change mitigation continue to shape the negotiations. At the same time, these countries are expected to have rather high shares of mid-century residual emissions in hard-to-abate sectors (Davis et al., 2018; Luderer et al., 2018; Bataille, 2020); challenges to and high costs of achieving their net zero targets will shift increasing attention toward CDR. This is not to argue that developments

\footnotetext{
${ }^{1}$ See definition by the IPCC, SR1.5: “Anthropogenic activities removing $\mathrm{CO}_{2}$ from the atmosphere and durably storing it in geological, terrestrial, or ocean reservoirs, or in products. It includes existing and potential anthropogenic enhancement of biological or geochemical sinks and direct air capture and storage, but excludes natural $\mathrm{CO}_{2}$ uptake not directly caused by human activities" (IPCC, 2018).
}

in other countries with different socio-economic structures, land resources, and climate policy priorities would be less relevant; an assessment of those countries is already planned in future research projects.

In addition to this first criterion, we limit this study to countries: (2) that have already integrated CDR in their existing policy mix; (3) in which the adoption of net zero targets has spurred a debate about the integration of CDR policies in the climate policy regime, or; (4) in which developments in niches, e.g., geochemical-based CDR, begin to put pressure on the existing regime. We therefore have an intentional bias toward countries that already deal with CDR and exclude those without CDR policies or emerging debates about it.

Based on these criteria, we identified the following set of case studies: the European Union $(E U)^{2}$ (and three of its Member States: Ireland, Germany, and Sweden), Norway, the United Kingdom (UK), New Zealand, and the United States $(\mathrm{US})^{3}$. Drawing on the case studies, provided by authors from each country and updated as of January 2021, we attempt to explore the varieties of CDR integration into climate policy regimes and propose an analytical typology to distinguish between different ways of approaching CDR politically.

\section{Analytical Framework}

To provide a systematic overview of recent developments in CDR policy across the cases, we developed an analytical framework consisting of five key dimensions and a template of questions. The framework is based on the multi-level perspective (MLP) heuristic of socio-technical transitions and integrates key findings of academic literature on CDR policy and governance. The following sections summarize key elements of the MLP and the CDR governance literature. Subsequently, we provide a brief overview of how these perspectives are being applied in this exploratory study to systematically track and assess CDR-related developments across the nine cases.

\section{Applying the Multi-Level Perspective (MLP) to CDR Policies}

Research on sustainability transitions has increased rapidly in the past 10 years (Köhler et al., 2019). The MLP on socio-technical transitions is one of the most prominent strands of transition studies. It provides a "middle range theory that conceptualizes overall dynamic patterns in socio-technical transitions" (Geels, 2011, p. 26) ${ }^{4}$. While it provides a straightforward heuristic for exploring transition processes, it should not be misunderstood as being capable of predicting future trajectories.

We do not attempt to provide a full MLP analysis of all nine case studies here. Rather, we apply the MLP heuristic to

\footnotetext{
${ }^{2}$ The EU as a supranational organization is not a full member of the OECD, but the European Commission takes part in its daily work.

${ }^{3}$ Throughout the initial process of case selection, experts from several other OECD countries were contacted (among them Japan and Canada) to decide whether these countries would fit into this set.

${ }^{4}$ For a discussion of middle range theory approaches, see Geels (2007).
} 
structure our effort to track and compare transitions toward integrating CDR policy. The advantage of the MLP perspective is its "relatively straightforward way of ordering and simplifying the analysis of complex, large-scale structural transformations" (Smith et al., 2010, p. 441) while still taking into account macro-political developments and developments in small niches. This makes the MLP our preferred choice over other more fine-grained theories ${ }^{5}$, concepts and heuristics in the-to our knowledge-first attempt to compare CDR policy development across countries.

The MLP sees transitions as non-linear processes resulting from interactions between developments at three different levels: First, the socio-technical regimes "represent the institutional structuring of existing systems leading to path dependence and incremental change" (Köhler et al., 2019, p. 4). Second, the exogenous socio-technical landscape, which consists of broader political, economic or demographic "contextual developments that influence the socio-technical regime and over which regime actors have little or no influence" (Geels et al., 2017, p. 465). And third, niche innovations, a level that describes "protected spaces and the locus for radical innovations" (Köhler et al., 2019, p. 4) which differ substantially from the currently dominant system and can put pressure on the existing regime (Geels et al., 2017). In addition, MLP adds a temporal dimension and distinguishes between the three phases of emergence, diffusion and reconfiguration (Geels et al., 2019).

Key strengths of heuristics such as the MLP are their capacity to identify path-dependencies, lock-in incentives and power distributions within a current system, as well as in emerging and diffusing innovation dynamics (Geels et al., 2017) - aspects that most integrated assessment models hardly address in their pathways (van Sluisveld et al., 2020). The strong focus on innovation in MLP should, however, not lead to an overly optimistic innovation bias; questions of possible "unanticipated consequences" (Merton, 1936, p. 894) and "intended but unrealized effects" (Hirschman, 1977, p. 131) should therefore always be part of analyzing transition processes.

\section{Key Insights From the CDR Policy Governance Literature}

The literature on scientific and technical aspects of CDR is growing rapidly (Minx et al., 2017) and, since the adoption of the Paris Agreement, literature on CDR governance and policymaking has also started to gain traction. Key issues addressed by scholars are the risk of mitigation obstruction (Morrow, 2014; Minx et al., 2018; McLaren et al., 2019), and the importance of policy and target design to address this risk, e.g., through prioritizing conventional mitigation and separate targets for emission reductions and removals (McLaren et al., 2019; Geden and Schenuit, 2020).

\footnotetext{
${ }^{5}$ Future research would gain from integrating insights from other strands of the sustainable transition literature, as well as other concepts developed in political science such as public policy paradigms Carson et al. (2010) and policy innovation Jordan and Huitema (2014).
}

Other important strands of the debate touch on the patterns of emerging societal debates and their possible polarization (Colvin et al., 2020) as well as the public perception (Cox et al., 2020), socio-political prioritization (Fridahl, 2017; Rodriguez et al., 2020), innovation dynamics (Nemet et al., 2018), incentive structures for research and deployment (Lomax et al., 2015; Cox and Edwards, 2019; Fajardy et al., 2019; Torvanger, 2019; Fridahl et al., 2020; Bellamy et al., 2021) and framings of different CDR methods (Bellamy and Osaka, 2020; Waller et al., 2020; Woroniecki et al., 2020). Furthermore, the literature highlights the role of CDR in integrated assessment modeling and possible implications for climate policy (Geden, 2016b; Beck and Mahony, 2018; Haikola et al., 2019; Workman et al., 2020), negative implications of deploying large-scale CDR for sustainability and biodiversity (Buck, 2016; Smith et al., 2019; Dooley et al., 2020; Honegger et al., 2020), and justice and equity considerations (Anderson and Peters, 2016; Peters and Geden, 2017; Shue, 2018; Fyson et al., 2020; Morrow et al., 2020; Pozo et al., 2020).

Especially in political debates, CDR methods are often separated with the rather ambiguous differentiation of "natural" and "technological" approaches. As framings of certain CDR methods have considerable political implications, in particular the terminology of "natural" or "nature-based" (Bellamy and Osaka, 2020; Waller et al., 2020; Woroniecki et al., 2020), we use the analytical and intended to be valueneutral distinction between ecosystem-based and geochemicalbased approaches ${ }^{6}$.

\section{Five Dimensions for Observing CDR Policy}

The following five dimensions represent an attempt to apply and bridge the conceptual work of the MLP on socio-technical transitions with existing research on CDR policy and governance to provide an analytical framework that allows systematic exploration of different case studies in a comparable way (see Table 1).

While the dimensions (1) institutional setting, actors, and coalitions, (3) policy instruments and (4) expert bodies and science attempt to explore key aspects of the MLPlevels socio-technical regimes and exogenous socio-technical landscape, dimension (5) particularly focuses on observing niche innovations. Dimension (2) CDR accounting and methods covers important aspects on definition, accounting and framings raised by the emerging academic CDR governance literature.

Limiting the comparison to these five dimensions means that neither all dimensions of MLP can be covered, nor can all aspects of CDR literature be fully represented. But this rather narrow and straightforward analytical framework enabled the systematic collection and comparison of facts on the ground in nine cases in this study. Analyses based on this material, however, must consider its limitations.

\footnotetext{
${ }^{6}$ While ecosystem-based methods refer to deliberately exploiting and enhancing sink functions of ecosystems, geochemical-based $\mathrm{CDR}$ describes $\mathrm{CO}_{2}$ capture from the atmosphere through technical devices and geological storage. Some CDR methods, such as BECCS, are hybrid forms, see e.g., United Nations Environmental Program (2017). Note that ecosystem-based methods are not necessarily positive for wider ecosystem services and biodiversity, as this depends on their mode and scale of implementation.
} 
TABLE 1 | Dimensions of observation.

\begin{tabular}{|c|c|}
\hline $\begin{array}{l}\text { (1) Institutional } \\
\text { setting, actors, } \\
\text { and coalitions }\end{array}$ & $\begin{array}{l}\text { - Overall institutional and political setting in domestic climate } \\
\text { - } \text { Molicy (incumbent regime) } \\
\text { [e.g., Paris Agreement, Sustainable Development Goals } \\
\text { (SDGs), ...] } \\
\text { - Actors and coalitions in CDR-related climate policy making } \\
\text { but also in broader societal debate [business/industry, } \\
\text { environmental non-governmental organizations } \\
\text { (ENGOs),...] }\end{array}$ \\
\hline $\begin{array}{l}\text { ( } 2 \text { ) CDR } \\
\text { accounting and } \\
\text { methods }\end{array}$ & $\begin{array}{l}\text { - Accounting practices of CDR toward domestic climate } \\
\text { targets and its relation to gross emission reductions } \\
\text { - Methods addressed and differences in accounting } \\
\text { - Groupings/separation and framings of different methods } \\
\text { (e.g., "technological"/vs. "natural" CDR) } \\
\text { - Socio-political prioritization of different methods }\end{array}$ \\
\hline $\begin{array}{l}\text { (3) Policy } \\
\text { instruments }\end{array}$ & $\begin{array}{l}\text { - Policy approach } \\
\text { - Timing and broader political circumstances } \\
\text { - Political struggles in public policy processes (main critique } \\
\text { vs. justification patterns) } \\
\text { - Relation to other climate, environmental and sustainability } \\
\text { policy instruments and targets (discursively, } \\
\text { politically, legally) }\end{array}$ \\
\hline $\begin{array}{l}\text { (4) Expert bodies } \\
\text { and science }\end{array}$ & $\begin{array}{l}\text { - Role for expert bodies and science more generally in societal } \\
\text { CDR debate as well as in public policy processes } \\
\text { - Role of IPCC reports (esp. 5th Assessment Report, SR1.5 } \\
\text { and Special Report on Climate Change and Land (SRCCL) } \\
\text { and domestic modeling or technology development }\end{array}$ \\
\hline $\begin{array}{l}\text { (5) Developments } \\
\text { in CDR niches }\end{array}$ & $\begin{array}{l}\text { - Developments with regard to CDR methods in "protective } \\
\text { spaces" that shield, nurture, empower (Smith and Raven, } \\
\text { 2012) } \\
\text { - Emerging business cases } \\
\text { - New actors that demand change in incumbent climate } \\
\text { policy regimes to integrate CDR }\end{array}$ \\
\hline
\end{tabular}

\section{CASE STUDIES}

The case studies presented in this section were conducted by experts from each country and followed the analytical framework presented above (see Table 1). In addition to the dimensions for observation, a template of guiding questions for each dimension was provided to the case study author teams to ensure comparable findings across cases. The five dimensions also structure the presentation of the highly condensed results in the following sections.

\section{European Union}

\section{Institutional Setting, Actors, and Coalitions}

The European Union (EU) is regarded as a key frontrunner in international climate policy and was a driving force behind the Paris Agreement. Among its Member States and between $\mathrm{EU}$ institutions, however, the appropriate level of ambition is contested (Rayner and Jordan, 2016). The EU's climate policies are separated into three regulatory pillars: the EU Emissions Trading System (EU ETS), the Effort Sharing Regulation (ESR), and the land use, land-use change and forestry (LULUCF) Regulation (Kulovesi and Oberthür, 2020). While the EU ETS covers emissions from power stations, energy-intensive industries and intra-European aviation, ESR sets national targets for emissions reductions in the transport, buildings, and agriculture sectors.

Since the adoption of the Paris Agreement and the IPCC SR1.5, the EU's executive arm, the European Commission, has started to address the issue of CDR proactively (European Commission, 2018). Recent policy initiatives are directly linked to the new 2050 target of net zero GHG emissions. The European Parliament and Member State governments in the Council of the EU-the co-legislators in EU policymaking - are still negotiating, but it is already apparent that the EU Member States differ considerably in how they approach CDR politically (see the case studies on Germany, Ireland, and Sweden). The shared competence between the $\mathrm{EU}$ and its Member States on the environment and therefore climate policy, combined with pathdependencies, deep-rooted conflict lines (Szulecki et al., 2016), and new distributional issues will shape the upcoming decisions (Geden and Schenuit, 2020). ENGOs are likely to play a vocal role in this process. Although ENGOs increasingly acknowledge the need for CDR to achieve the net zero target, their positions are often critical, especially with regard to what some call largescale "artificial negative emissions technologies" (Climate Action Network, 2018, p. 3). Other advocacy groups have started to call for integrating CDR into EU climate policy (e.g., Bellona). Furthermore, governmental and industry representatives of the Northern Lights project (see the case study on Norway) turned to the EU to promote cooperation on carbon capture and storage (CCS), including bioenergy with CCS (BECCS).

\section{CDR Accounting and Methods}

The Commission regards CDR as key to achieving net zero GHG emissions by 2050. Its modeling shows that net zero pathways require ecosystem- (LULUCF) and geochemical-based direct air capture and CCS (DACCS) CDR, as well as BECCS as a hybrid form. At present, the EU does not fully account for LULUCF removals toward its economy-wide mitigation targets of $-40 \%$ by 2030 compared to 1990 levels. In the context of revising the target $(-55 \%)$ and its new Nationally Determined Contribution (NDC) submitted in December 2020, the Commission and the Member States, however, modified the accounting toward a full consideration of the LULUCF sink. It is likely that the rather unspecific differentiation between "natural" and "technological" CDR will become a controversial issue. ENGOs have invested substantial political capital in this differentiation, and the Member States have different socio-political CDR prioritizations (Geden and Schenuit, 2020).

\section{Policy Instruments}

The current 2030 Climate and Energy Framework established in 2018 includes no distinct CDR policy. However, given the new 2030 target, this will change by 2022. The current LULUCF Regulation contains a "no-debit rule" meaning that countries are obliged to balance any emissions with removals in the LULUCF sector. To a very limited extent, LULUCF credits can be counted toward mitigation targets in the ESR sector ( $~ 1 \%$ of 2005 ESR emissions). This flexibility, however, was not explicitly framed as CDR policy, i.e., intentionally incentivizing removal capacities to achieve an economy-wide mitigation target, but rather as 
acknowledging the hard-to-abate emissions in the politically influential agricultural sector (Böttcher et al., 2019; Matthews, 2019). For now, explicit CDR policies are only under preparation by the Commission. Gradually, however, they are being taken up by the Council and the Parliament. These initiatives focus mostly on ecosystem-based methods: In its Circular Economy Action Plan, the Commission announced a regulatory framework for the certification of CDR by 2023. In its Farm to Fork Strategy, the Commission proposed to use money from the Common Agriculture Policy to reward farmers and foresters who sequester carbon. Apart from that, most existing initiatives are linked to research and innovation funding. The EU's Horizon 2020 program funds large CDR research projects and the EU ETS Innovation Fund ( $€ 10$ billion) is open for applications from CDR and CCS pilot and demonstration plants. Furthermore, the Commission supports new geological storage projects such as Porthos in Rotterdam and Northern Lights politically and financially (see the case study on Norway). Almost all climate legislation is up for re-negotiation in 2021 and 2022 in the context of upgrading the 2030 target. CDR will likely be addressed in these revisions, maybe even in the EU ETS (Rickels et al., 2020).

\section{Expert Bodies and Science}

The Commission refers to the IPCC SR1.5 and in-house modeling efforts to justify CDR (European Commission, 2018). This justification is in line with a paradigm in EU climate policy that attaches great importance to evidence-based target setting and policy design (Geden et al., 2018). Concurrently, the EU plays a key role in funding the production and mobilization of climate science, in particular, it played a decisive role in the financing of the integrated assessment modeling community (Lövbrand, 2011; Cointe et al., 2019)—one of the key gateways for the diffusion of the CDR issue on the political agenda (Low and Schäfer, 2020). Although the EU's long-term strategy models net negative $\mathrm{CO}_{2}$ in the second half of the century (European Commission, 2018) and legislation includes language on the need for it, actual target-setting and other policy initiatives do not address the issue so far; it is almost exclusively addressed by climate scientists.

\section{Developments in CDR Niches}

With regard to CDR niches, the involvement of the Commission in CCS projects in the Netherlands and Norway and the funding opportunities for researching and demonstrating CDR under the EU ETS Innovation Fund are the most important developments. In November 2020, three EU Member States (Netherlands, Denmark, and Sweden) together with Norway published a "Nonpaper on Carbon Capture and Storage" in which they stress the importance of CCS as well as $\mathrm{CO}_{2}$ removals to achieve the EU's goal of climate neutrality (Klima- Energi-og Forsyningsudvalget Denmark, 2020). Other niche developments can be best observed at the Member State level (see the case studies on Germany, Ireland, and Sweden).

\section{Germany}

\section{Institutional Setting, Actors, and Coalitions}

Germany is often perceived as a frontrunner in crafting mitigation policies. Since the late 1990, German policymakers have promoted the "Energiewende" (energy transition) and its main purpose of supporting the expansion of renewable energy sources to reduce $\mathrm{CO}_{2}$ emissions. At the same time, its climate policy is deeply interwoven with EU policy making (see EU case), occasionally creating tensions between the largest EU Member State and the EU level (Jänicke, 2017). Although German climate policy explicitly refers to the net zero GHG target stemming from Art. 4 of the legally-binding Paris Agreement (German Government, 2016), the issue of CDR to balance residual emissions is not explicitly addressed. This holds also true for the Climate Law adopted in 2019. Neither the balancing of residual emissions nor net-negative emissions beyond 2050 are addressed in the law (Bundesgesetzblatt, 2019).

After the German government decided to follow the EU Commission's proposal to set a net zero GHG emissions target in 2019, the fact that achieving net zero target requires removals, both ecosystem-based and geochemical-based got increasing attention in German climate policy (Prognos, Öko-Institut, Wuppertal-Institut, 2020). In general, however, the issue of CDR is approached with restraint. The Free Democratic Party is the only party in the German parliament calling for a proactive approach to CDR. The political reluctance is linked to the strong political path-dependencies created by the energy transition and the low level of public acceptance of CCS (Dütschke et al., 2016). However, the acknowledgment that residual emissions must be balanced to achieve net zero GHG emissions in 2050 is likely to lead to an intensified CDR debate and incremental modifications of existing climate policy. ENGOs increasingly acknowledge the fact that some carbon removal will be needed, and support for enhancing "natural" sinks is being expressed (Deutscher Naturschutz Ring, 2020). Their position toward integrating geochemical-based CDR remains very skeptical. Their main arguments against the integration are concerns about mitigation obstruction as well as strong rejection of CCS. The German industry has so far not been openly calling for the integration of $\mathrm{CDR}$ in future climate policy.

\section{CDR Accounting and Methods}

CDR is not yet accounted for in national mitigation targets, neither natural (e.g., enhanced LULUCF sink) nor geochemicalbased methods (except for limited flexibilities, see EU case). However, EU Member States including the German government and the EU Commission now support a proposal of changing the accounting methods for climate targets at EU level, incl. the 2030 target, toward a "net" emissions logic. Such a reform would then likely also be implemented in the German climate law.

\section{Policy Instruments}

The emerging CDR debate in Germany is shaped by the differentiation between "natural" and "technological" methods. Options linked to CCS in particular are quite contested. In the years before the incremental acknowledgment of the need for CDR to neutralize residual emissions in the context of net zero targets, deliberate CDR was not discussed by political actors but only by climate scientists and usually dismissed as a form of climate engineering. At the national level, no CDRrelated policy instruments exist yet. The developments at EU level, however, will shape German climate policy substantially. 
Not only because of EU competencies in climate and energy policy, but also because it is easier for German policymakers to elevate a rather controversial issue to Brussels. As the German LULUCF sink is projected to decrease and turn into a source of emissions (Umweltbundesamt, 2020) and the existing EU legislation already requires to adhere to the "no-debit rule" (see EU case), the development of policies that aim for enhancing LULUCF removals are to be expected.

\section{Expert Bodies and Science}

In the National Energy and Climate Plan 2030, submitted to the EU in 2020, the German government addresses both "natural" CDR ("plant growth") and "technological" CDR ("direct air capture"). It is being noted that research will be stepped up (Bundesministerium für Wirtschaft und Energie, 2020, p. 61). A research initiative is also announced with regard to the enhancement of the sink function of soils and forests (Bundesministerium für Wirtschaft und Energie, 2020, p. 119). The integration of controversial topics into the political debate through formalized expert bodies and research funding is a common approach in Germany (Jasanoff, 2005). For 2021, the Federal Ministry for Education and Research announced two large research funding lines (Bundesministerium für Bildung und Forschung, 2020a,b).

The debate on CDR entered the policy debate only after the IPCC's SR1.5 in 2018. Policymakers in parliament and public officials in the relevant ministries, however, are still reluctant. Since the adoption of the net zero target, the debate is incrementally shifting and a discussion about funding for researching and developing CDR emerges. So far, CDR measures were almost absent from domestic modeling efforts (Hahn et al., 2020). However, first studies on achieving net zero GHG emissions indicate the need for large-scale geochemical-based CDR (5\% of 1990 emissions) (Prognos, Öko-Institut, WuppertalInstitut, 2020). The issue of net-negative emissions in the second half of the century, however, is only addressed by climate scientists so far.

\section{Developments in CDR Niches}

Due to the aforementioned strong path dependencies in German climate policy, the support for CDR niches is rather limited. The new funding lines indicate emerging support for research and development but not for deployment of geochemical-based CDR. An increasing amount of German companies are cooperating with internationally emerging CDR businesses in order to explore possible ways to achieve voluntary climate targets, e.g., Audi/Volkswagen with ClimeWorks in Iceland (VW, 2020). The decreasing LULUCF sink and existing regulatory obligations might put pressure on German climate policy regime and could accelerate the support for niches.

\section{Ireland}

\section{Institutional Setting, Actors, and Coalitions}

Ireland expresses consistent aspirational support for effective climate policies, but following the financial crisis of 2008 it generally prioritized economic recovery. Within the EU's multilevel processes Ireland has played a generally constructive role but resisting high ambition, and maximizing so-called "flexibilities." The role of GHG sinks, and specifically forestrybased sinks, has been part of Irish policy since the adoption of the Kyoto protocol. Ireland's compliance with its (relatively modest) obligations under the first commitment period of the protocol relied on including accounting for forestry sinks. However, the overall Irish LULUCF sector continues to be a net GHG source rather than sink. The government that took office in 2020 tabled a draft for new national climate action legislation, including a statutory net zero objective for 2050, explicitly defined as a balance between GHG emissions and removals (Irish Government, 2020).

Since 2016, after IPCC's AR5 and the adoption of the Paris Agreement, there is active discussion of net removals among a small number of scientific experts, agencies, and relevant government departments but not apparently extending to senior ministerial level. Among these, views are very preliminary, but there is some rough consensus on the need for strengthening national policy capacity and understanding. To date, geochemical-based CDR has played virtually no role in public discourse. Among NGO actors, CDR is largely viewed with suspicion and assumed to be a device for mitigation obstruction. There is active consideration by industry actors in the agriculture and forestry sectors, focused on potential "credits" (financial or otherwise) to be gained by accounting of gross removals. The influential Irish agri-food sector strongly promotes the potential role of land use removals.

\section{CDR Accounting and Methods}

Current national policy ring-fences any removals attributable to forestry as implicitly contributing to a 2050 approach to GHG neutrality within the agriculture, forestry, and other land use (AFOLU) sector, separate from all other sectors. The new legislation would, if enacted, supersede this by establishing an integrated economy-wide GHG neutral by 2050 target. Afforestation is incentivised, but Ireland is characterized by low existing forest cover and afforestation rates have consistently fallen short of targets. Relatively maximal flexibility for LULUCF removals was also sought under the EU Effort Sharing Regulation (ESR) for 2021-2030 (see EU case). There is a separation between discussion of forestry and soil carbon sequestration as against geochemical-based approaches, partly due to relative familiarity and deployment maturity, and because the agriculture sector views the former as tacitly balancing $\mathrm{N}_{2} \mathrm{O}$ and $\mathrm{CH}_{4}$ under the EU ESR. Bioenergy policy should cut across this: but current bioenergy development is still assessed in terms of unabated use in direct fossil fuel substitution, rather than potential combination with CCS for CDR (BECCS). There is some ongoing exploration of CCS deployment for fossil fuel emissions abatement, but not CDR.

\section{Policy Instruments}

So far, no explicit CDR policy exists, except for incentivising private forestry development. But this policy is generally perceived as primarily about promoting forestry as an economic 
sector rather than climate mitigation. The proposed climate bill refers to a need for policy flexibility "to take advantage of opportunities ... to accelerate the removal of greenhouse gases" (Irish Government, 2020, p. 9). It also proposes the adoption of a rolling programme of 5-year cumulative GHG budgets, though the draft is equivocal as to whether these would be net, or separated into gross emission and removal components. Perhaps more significantly, it makes provision for potential allocation of funding for "projects that seek to increase the removal of greenhouse gas, particularly nature based solutions that enhance biodiversity" (emphasis added, Irish Government, 2020, p. 51).

\section{Expert Bodies and Science}

In light of AR5 and the Paris Agreement, the Irish Environmental Protection Agency sponsored a research project to provide a preliminary assessment of the overall potential for negative emissions technologies in Ireland (McMullin et al., 2020). From 2017 onwards, reports of the national Climate Change Advisory Council (CCAC) have started arguing more clearly and explicitly for enhancement of forestry specifically as mitigation. The most recent CCAC annual report (Climate Change Advisory Council, 2020) contained, for the first time, a full section introducing and reviewing the potential role of CDR in Irish climate action. IPCC's SR1.5 has contributed to the expert discussion. Especially to the most recent documents and reports from the Irish Climate Change Advisory Council. Since then, net zero by 2050 has acquired a sort of totemic usage. Domestic academic analysis is starting to incorporate the finite cumulative GHG budget framing, including downscaling to the national level (based on explicit interpretations of prudence and equity) and this in turn is strengthening consideration of CDR (Glynn et al., 2018; McMullin et al., 2019; McMullin and Price, 2020). The fact that IPCC scenarios assume large scale global net-negative emissions (post 2050) has so far received only marginal political attention. A CCAC communication to Government on the subject of setting national carbon budgets noted that any overshoot or exceedance "will have to be recovered with negative emissions" (Climate Change Advisory Council, 2019, p. 2). It is unclear if this message is yet seriously percolating into national policy thinking, and is not an aspect of wider public discourse. But local NGOs are beginning to raise the issue, particularly in the context of global and intergenerational climate justice.

\section{Developments in CDR Niches}

In general, a perception of Ireland as a technology taker rather than innovator in heavy industry sectors prevails in Irish climate policy. From a general industry point of view, interest will remain very limited unless there are plausibly profitably CDR business models. The governmental support for developing or deploying niche CDR methods is therefore rather limited. The new climate bill, however, might change this perspective.

\section{Sweden}

\section{Institutional Setting, Actors, and Coalitions}

Sweden has pioneered climate policy development since the 1980s. Around the mid-1980s, it adopted several policies targeting energy efficiency and, by the early 1990s, became one of the first countries to instigate a carbon tax. Today, Swedish climate policy is highly interwoven with EU policies and Sweden is traditionally one of the EU Member States with the highest climate ambitions. Although the Swedish political debate on CDR is old and tied to forestry, it intensified after the adoption of the Paris Agreement and following a broad Parliamentary approval of the Swedish climate law in 2017 (Government of Sweden, 2017). The climate law was preceded by intense debate among researchers, NGOs, and politicians on the appropriateness of planning for BECCS to contribute to longterm climate targets. While the Swedish BECCS potential is high, planning for BECCS, it was argued, could lead to near-term mitigation obstruction followed by inability to meet the longterm target if BECCS did not deliver. Policymakers agreed on a compromise, with separate targets for emission reductions and so-called supplementary measures.

\section{CDR Accounting and Methods}

The separated target structure established by the Swedish climate law distinguishes between emissions reductions (at least $-85 \%$ compared to 1990 levels) and supplementary measures (maximum 15\%), i.e., CDR through targeting additional enhancement of LULUCF sinks and BECCS (Government of Sweden, 2016) as well as international offsetting. Supplementary measures have mostly been justified as a means to provide flexibility to the milestone targets and to balance hard-to-mitigate residual emissions in 2045. While all Swedish climate policy is anchored in the climate law and framework, CDR-related policies are largely done separately.

\section{Policy Instruments}

In 2020, a government committee proposed a strategy to realize the supplementary measures (Government of Sweden, 2020). Although international offsetting was forwarded as one alternative, the committee suggested to minimizing offsetting and to instead focus on BECCS and enhanced LULUCF. The over 50 actions proposed by the strategy include state-led reverse auctions for BECCS, improved coordination, increased funding to afforestation, agroforestry, rewetting of drained peatlands, and to push for an EU-wide BECCS policy and improved monitoring and reporting rules. The proposed strategy has received substantial backing by Swedish industry and civil society. Some politicians have indicated resistance to subsidized BECCS, including representatives of the Green Party, while others have largely reacted with silence. In January 2021, the Swedish Government tasked the Swedish Energy Agency to design a support scheme for BECCS to be implemented in 2022 either as a reverse auction or as a flat subsidy (Government of Sweden, 2021). Forest and energy companies are requesting policy-induced economic incentives to deploy BECCS and are also generally of the opinion that biomass may contribute to decarbonization and negative emissions in many other ways (Rodriguez et al., 2020). Several NGOs have criticized the strategy for not capitalizing fully on the potential of enhanced "natural" carbon sinks.

While forest-based CDR has long been discussed, LULUCF sinks are not foreseen as the main CDR method; LULUCF 
sources and sinks are reported but unaccounted toward the climate targets. Taking the LULUCF sink into full account would enable net zero emissions soon after the mid-2020s, provided that fossil emissions continue to decline. The proposal is to only account for additional LULUCF removals that are a direct effect of new supplementary measures policy and that are not necessary to meet the no-debit target in the EU LULUCF Regulation (Government of Sweden, 2016, 2020). In addition to initiatives in the context of the climate law, policy measures for LULUCF sinks exist, a few existing policy measures also target BECCS and biochar. These instruments include the Industrial Leap Scheme Industriklivet, an investment fund with a specific appropriation for BECCS RDD\&D, and the Climate Leap Program Klimatklivet and the Rural Development Programme that supports biochar market introduction. Regulatory clarity on $\mathrm{CO}_{2}$ transport and storage is also in force, in response to EU regulation (Government of Sweden, 2014).

\section{Expert Bodies and Science}

When the debate on fossil CCS intensified in the late 1990s, Swedish researchers started exploring BECCS as a source of negative emissions (Obersteiner et al., 2001; Möllersten, 2002) and to expand the technology portfolios of integrated assessment models (Azar et al., 2001). At the time of the approval of SR1.5, the Swedish climate law had already been passed in Parliament. By then, the Swedish debate had matured to take note of the high uncertainties related to BECCS but also to distinguish between the large trade-offs associated with the widespread BECCS deployment assumed in many global scenarios and the more limited but less problem-struck domestic potential for BECCS (Fridahl, 2018). In the process of designing the separated targets, domestic modeling played an important role. It was used both to arrive at the total target quantity for supplementary measures in 2045, and to argue for bringing the target forward from 2050 to 2045 . The Swedish potential for net-negative emissions in the second half of the century is also discussed in expert circles and established as a climate objective yet in unspecified qualitative terms (to achieve net-negative emissions after 2045).

\section{Developments in CDR Niches}

Due to strong governmental support for research, development, and deployment, BECCS is developing quite fast. Most prominently, Stockholm Exergi, an energy utility, pledges to become "climate positive" (i.e., net-negative) by 2025, relying on its own production of biochar and BECCS deployment to deliver on its pledge. About 10 other companies are also planning to implement BECCS between 2025 and 2030.

\section{Norway}

\section{Institutional Setting, Actors, and Coalitions}

Norway's climate target is to reduce GHG emissions by $50-55 \%$ by 2030 compared to 1990 but does not have a specific net zero target. By 2050 the ambition is to reduce GHG emissions by 90-95\%. The industry and energy sectors are fully integrated in the EU ETS, whereas other policy instruments are directed at the transportation, agriculture, buildings, and waste sectors. According to the EU's LULUCF regulation, which Norway is associated with, the no-debit rule applies to LULUCF by 2030 (see EU case). The CDR story in Norway is short, and there is not much public debate about CDR. However, the CCS story is longer-stretching back to the 80 s in terms of research and mid90 in terms of the first industrial application. CCS is not a CDR approach on its own but needed for BECCS and DACCS. CCS entered the public debate in the early 1990s, and gained traction from 1996 onwards after $\mathrm{CO}_{2}$ was separated from natural gas at the Sleipner platform to make the gas commercial and geologically stored. The subsequent debate on CCS in Norway was associated with power production from natural gas. CCS became a compromise between industrial development based on natural gas and climate policy. Full-chain CDR operations, foremost biomass use combined with $\mathrm{CO}_{2}$ capture in industry and biochar, have only been on the debate agenda for the last decade, catalyzed by IPCC's SR1.5 from 2018.

The interest in industry-based CCS has picked up in the last years, foremost in some energy-intensive industries, to capture fossil- and process-related $\mathrm{CO}_{2}$ emissions, or to produce hydrogen from natural gas combined with CCS. These industries also have plans to replace some of the fossil inputs with biogenic materials, which would establish a CDR chain. One example is the planned carbon capture operation at the waste incineration plant of Fortum Oslo Varme AS. However, so far little attention has been given to specialized BECCS. The agricultural sector has taken some interest in biochar and established a network (Norsk Biokullnettverk, 2020). Technology focused environmental NGOs accept geochemical-based CDR, whereas the nature conservation focused NGOs favor ecosystembased CDR. Industry groupings and agriculture see themselves as stakeholders in CDR, but still expect significant public facilitation in terms of public funding and an improved policy framework.

\section{CDR Accounting and Methods}

Norway has had a net $\mathrm{CO}_{2}$ sink through forest growth for decades but has been cautious to include this in the national GHG accounting, with a view to the country's position on sinks in international climate policy negotiations. In the case of BECCS, waste incineration, and biogenic inputs for industry with CCS, removals can be accounted for if these can be subtracted from emissions of $\mathrm{CO}_{2}$ and other GHG. There is a challenge with CDR in industry due to the EU ETS, however, since biomass is included in the baseline (i.e., assumed to be $\mathrm{CO}_{2}$-neutral) and biomass-based entities are excluded from the trading system.

\section{Policy Instruments}

Explicit CDR policies are currently almost absent from Norwegian climate regulation. So far government financial support for R\&D has been the major policy instrument for CCS and CDR development. Since Norway is fully linked to the EU ETS, CDR-related funding from the EU's Innovation fund (see EU case) will also provide some CDR incentives in Norway. As part of a broader debate, one proposal is to establish a specific fund to catalyze CCS and CDR deployment in industries. Regarding forestry, in 2016 a scheme for enhanced carbon fixation in forests was introduced, with economic support for forest fertilization, denser tree planting, and development 
of improved tree species. Aside from managing the net $\mathrm{CO}_{2}$ sink of forests, there will not be much development on other CDR methods.

The Northern Lights project, a CCS project to transport and sequester $\mathrm{CO}_{2}$ from Norway and other countries, is a key initiative. This project is part of emerging international full-CDR chains and potentially a component of future CDR business cases in Norway and beyond.

\section{Expert Bodies and Science}

The first actors to push both CCS and CDR into the policy debate were scientific experts and some NGOs. Aside from an earlier start in the scientific community, the public attention and debate first picked up after recent IPCC reports. In Norway, this awakening has merged with the longer-term understanding of the need and potential for CCS to reduce GHG emissions, and Norway being in a promising position to facilitate the required technology development, not the least regarding storage of $\mathrm{CO}_{2}$.

\section{Developments in CDR Niches}

In Norway, several CDR-related CCS projects are emerging, financed by the government as well as possibly by the EU's Innovation Fund. In September 2020, the government launched the project Langskip, announcing that a full-scale CCS facility at Norcem Heidelberg Cement, Brevik, will receive close to full government funding. Furthermore, a full-scale CCS facility at the Fortum Oslo Varme AS waste incineration plant will receive almost $50 \%$ government funding, contingent on remaining funding from own and other sources. Parts of these processes can be regarded as CDR. The Northern Lights initiative is the third component, in which an infrastructure for transportation and storage of $\mathrm{CO}_{2}$ under the North Sea seabed is developed, supported by Equinor, Shell, Total, and the Norwegian government. Companies from other European countries are invited to join. So far, companies from Norway, the UK, the US, Ireland, Sweden, Belgium, France, and Germany, have expressed an interest. More generally, there is widespread industrial interest in Norway to reduce industry-related $\mathrm{CO}_{2}$ emissions through installing CCS facilities and using biogenic resources.

\section{United Kingdom}

\section{Institutional Setting, Actors, and Coalitions}

Before submitting its first NDC in 2020, the UK had made its commitments under the UNFCCC as part of the EU. The UK has had comprehensive emission targets set by domestic legislation since 2008, however, and withdrawal from the EU does not appear to have changed its overall positioning as an international leader. The legislation of the 2050 target for a UK GHG reduction of at least $100 \%$ (i.e., net zero) (UK Government, 2019) has raised the profile of the debate around CDR, in the UK often referred to as Greenhouse Gas Removal (GGR) to keep open the possibility of non- $\mathrm{CO}_{2}$ approaches. $\mathrm{CDR}$ entered the national political debate with the publication of the 2016 report "UK Climate Action following the Paris Agreement" by the Committee on Climate Change (CCC) (Committee on Climate
Change, 2016). Before that, CDR was not explicitly addressed as a topic but several initiatives indicated implicit CDR policy. Reforestation was a policy topic in the UK early on after a history of heavy deforestation. The UK had integrated carbon storage as a goal of forestry by 1994 and committed to create more woodland in the context of climate targets in 2009 (Raum and Potter, 2015). Increased tree planting became a high-profile campaign issue during the 2019 election, with the environment, and carbon in particular, highlighted as a key motivation.

Recently, some businesses and industries have promoted geochemical-based CDR. Perhaps the most notable (in terms of potential scale) is Drax, the UK's largest thermal power station, which is trialing carbon capture on its biomass-fired units with the aim of becoming a BECCS facility. Other, smaller-scale CDR start-ups are also emerging. Conclusions from the UK Citizens' Assembly on Climate Change suggest a majority of the public prefers ecosystem-based approaches to geochemical approaches. There is however some support for research into "engineered" $\mathrm{CDR}$. Common concerns include $\mathrm{CO}_{2}$ leaks from storage and that CDR fails to address the root cause of the problem (Climate Assembly UK, 2020). Other UK surveys confirm this, and suggest publics may not accept removal unless accompanied by ambitious near-term emission reductions (Cox et al., 2020). The position of UK ENGOs on CDR is rather mixed. Mitigation deterrence is a concern, although at least some consider a need for geochemical CDR alongside widespread emissions cuts (Friends of the Earth, 2018).

\section{CDR Accounting and Methods}

In UK mitigation targets, emissions and removals are treated equally in accounting and LULUCF sources and sinks are included (UK Government, 2019). The legislation only mentions the LULUCF sector in reference to removals which can be accounted for in targets. This implies that any CDR reported outside the LULUCF sector (e.g., BECCS, DACCS) would not be included, however, an adjustment to the legislation would at least in principle be simple.

\section{Policy Instruments}

The most developed area of policy relating to CDR in the UK is for forestry. A framework for monitoring, reporting, and verification (MRV) of voluntary actions to increase carbon in forests has been developed as the Woodland Carbon Code. Incentives exist in the form of grants and, more recently, the Woodland Carbon Guarantee which provides long-term prices for carbon credits. Several policies are in place to reduce the wider negative impacts of these policies (UK Government, 2018).

Despite previous failed attempts to initiate CCS in the UK, the government intends to deploy CCS at scale by the mid-2020s. It has announced a CCS Infrastructure Fund of $£ 1$ billion to build four clusters by 2030 (UK Government, 2020b). Support has been given to several innovation projects, FEED studies and strategy documents, and a consultation carried out on business models to support different CCS applications, including BECCS. The

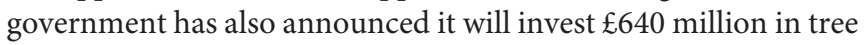
planting and peatland restoration (i.e., enhanced soil carbon) in England (UK Government, 2020a), is studying policy options to 
incentivise a range of CDR methods (Vivid Economics, 2019) and has noted its openness to considering future inclusion in carbon pricing mechanisms. Up to $£ 100 \mathrm{~m}$ support for innovation in CDR has been announced (UK Government, 2020a).

\section{Expert Bodies and Science}

The UK's approach is guided substantially by the CCC. Its advice emphasizes independent expertise and scenario building, with the overall timing and scope of domestic action guided by global pathways necessary to meet the Paris Agreement, taken primarily from the IPCC's SR1.5 (Committee on Climate Change, 2019). The CCC is now analyzing CDR as a sector alongside other more traditional sectors such as power and transport, and has offered a package of policy recommendations (Committee on Climate Change, 2020). The wider academic climate research community has also been a key player in the debate. The UK research councils have already funded one programme of CDR research and are commissioning a new programme of demonstration. A report on CDR was published by the Royal Society and Royal Academy of Engineering in 2018 (Royal Society Royal Academy of Engineering, 2018).

\section{Developments in CDR Niches}

In the UK, CDR niches are supported proactively by the government. The substantial amounts of funding for research, demonstrating, and deployments indicate that the UK intends to develop into a frontrunner and a technology-provider in the context of CDR. The government has stated "we want the UK's entrepreneurs, universities and engineering industries to be well-placed to exploit the advantages of global demand for these new technologies" (UK Government, 2017, p. 57). Companies, including established businesses and start-ups, are exploring CDR.

\section{Australia \\ Institutional Setting, Actors, and Coalitions}

Climate policy in Australia is a contested policy field, shaped by high vulnerabilities to the impacts of climate change on the one hand and politically influential fossil fuel interests on the other. Australia has a weak pledge for emissions reduction to the Paris climate agreement (Den Elzen et al., 2019), with a commitment to $26-28 \%$ reduction on 2005 levels by 2030 , though eschewing any formal commitment to a net zero target. The federallevel reticence around climate targets is contrasted sharply by all Australian states and territories, which have adopted net zero by 2050 (or sooner) targets (Climate Council, 2020). The issue of CDR has been implicitly present in Australia's climate policy for some time. After the publication of the King Review, the Australian Government released its first Statement on the Technology Investment Roadmap (Department of Industry, Science, Energy and Resources, Australia, 2020c) in which CDR was acknowledged. The statement outlines prioritized technologies, notably including carbon capture and storage (CCS) (plus compression, transport, etc.) explicitly justified by the pursuit of negative emissions. The Statement also includes prioritization of soil carbon, a watching brief on direct air capture (DAC), and carbon capture and use (CCU) as an emerging technology. NGOs and private sector actors have not engaged substantively with CDR in public discourse (outside of the highprofile debates about CCS). The changes in 2020 sit atop a legacy of deeply contested climate policy in Australia (Crowley, 2017); a legacy which offers important context for CDR (Colvin et al., 2020) and highlights the implicit governance of some CDR approaches in Australia.

\section{CDR Accounting and Methods}

In the National Greenhouse Gas Inventory, emissions and removals by sector including LULUCF, are aggregated to provide a net-total for the country. Ecosystem-based CDR methods are already an implicit part of the policy mix in Australia and regarded as fungible with conventional mitigation. In recent years, LULUCF contributed net-removals to Australia's total emissions (Department of Industry, Science, Energy and Resources, Australia, 2020b). The centrality of technical methods, particularly CCS, to the 2020 Statement further complicates how CDR has entered Australia's climate policy discourse. CCS in Australia has been a critical technology underpinning "clean coal" rhetoric, which was first advanced in the 1990s and considered a delaying tactic for meaningful emissions reduction (Marshall, 2016). Therefore, the promotion of CCS in 2020 initiative raises the potential that CDR will be perceived or used as the latest iteration of emissions reduction delay.

\section{Policy Instruments}

The Climate Solutions/Emissions Reduction Fund (ERF) is Australia's primary climate policy instrument. This economy wide abatement subsidy scheme was introduced in 2014, and uses reverse auctions to "purchase carbon abatement at the lowest per-unit cost” (Evans, 2018, p. 39). Under the ERF, CDR has arguably been enacted in Australia via ecosystem-based approaches such as soil carbon sequestration, tree planting, and improved grazing practices (Department of Industry, Science, Energy and Resources, Australia, 2020a). In Australia's climate policy discourse, many consider the ERF to be a suboptimal policy option (Burke, 2016). It was part of the "Direct Action" approach, implemented following repeal of Australia's shortlived carbon price. This "implementation and reversal" period of climate policy (Chan, 2018, p. 302) was marked by negative and divisive politics and well-financed and influential fossil fuel industry campaigning (McKnight and Hobbs, 2018). The consequence is that the divisive politics, the contested Direct Action approach, and the forgone carbon price have fostered an industry-first, climate-later view of the political intent of the ERF.

The government response to the King Review noted that efforts to develop methods for including CCS \& CCUS under the ERF are in development (Australian Government, 2020). Due to the fact that the ERF already includes carbon removal practices, the regulatory effort to include geochemical-based CDR would be comparatively low. Approaches under the ERF that may be considered CDR have been positioned in the context of emissions reductions (and now, climate solutions), rather than explicitly as CDR. 


\section{Expert Bodies and Science}

The scientific community is increasingly engaging with the issue of CDR (Australian Academy of Science, 2018; Dunne, 2018) and an expert panel appointed by the government provided the King Review (Carbon Abatement Panel, 2020), which noted the IPCC and IEA regard negative emissions technologies as significant for the Paris Agreement goals.

\section{Developments in CDR Niches}

Australia has an established sector focused on ecosystem-based CDR ("carbon farming") that has been engaging with the ERF and voluntary markets (Evans, 2018). With regard to geochemical-based CDR there are few early movers. Notably, Mineral Carbonation International is an emerging Australian company, and the key entity of $\mathrm{CO}_{2}$ Value Australia, a peak body representing the nascent carbon utilization sector. The decision to expand the scope for investment beyond renewable energy to include low, zero, and negative emissions technologies of the government agencies Climate Change Authority, Australian Renewable Energy Agency and the Clean Energy Finance Corporation may provide support for niche development. Cooperation by research, industry, and the government may guide the future development of CDR via the ERF and Technology Investment Roadmap toward a productive policy environment in which CDR is not in effect nor perception a $2020+$ iteration of "clean coal" emissions reduction delay. CDR as a climate-industry win-win may promote repair of destructive climate politics and inadequate climate policy, and governance via the existing ERF mechanism may accelerate implementation.

\section{New Zealand}

\section{Institutional Setting, Actors, and Coalitions}

Climate policy in New Zealand to date has been shaped by a strong focus on a price-based, least cost approach to mitigation, combined with the significant economic role of the primary (land-use) sector with high emissions from agriculture and removals from afforestation. CDR from afforestation has been integral to New Zealand's conceptualization of climate change targets and policy from the early 1990s, recognizing that gross $\mathrm{CO}_{2}$ emissions were projected to increase, but an increasing forest sink would partly compensate for this growth. New Zealand strongly argued for inclusion of carbon sinks in the design of the Kyoto Protocol and the formulation of gross-net emission targets. The domestic debate remained during the late 1990 s and early 2000s about the most appropriate incentives for enhancing forest sinks.

Afforestation remains a significant element of New Zealand's approach to meeting its NDC and 2050 emission targets as it provides a comparatively cheap and significant carbon $\operatorname{sink}^{7}$. Despite initial concerns in the 1990s, the forestry industry is broadly supportive of plantation forests receiving units that can be traded in the emissions trading scheme (ETS). However, different groups in NZ are increasingly expressing concern.

\footnotetext{
${ }^{7}$ The net zero target covers all gases other than biogenic methane (for NZ, essentially $\mathrm{CO}_{2}$ and $\mathrm{N}_{2} \mathrm{O}$ ). For biogenic methane, the government has set a separate reduction target range of -24 to $-47 \%$ reduction by 2050 based on IPCC SR1.5.
}

Rural community groups are concerned about the potential loss of employment, population and associated effects on the community and services if widespread afforestation occurs at the expense of sheep and extensive beef farms (Harrison and Bruce, 2019). Some rural advocates regard the significant reliance on afforestation as evidence of a rural/urban split, i.e., urban elites evading the need to reduce their own (gross) emissions by relying on carbon sequestration occurring on the backs of rural communities. Environmental NGOs are primarily concerned that excessive reliance on CDR may lead to mitigation obstruction, along with risks to the permanence of forest sinks. Other concerns relate to the dominance of an introduced tree species (Pinus radiata) and only limited support for biodiversity goals that could be derived from slower growing native forests.

\section{CDR Accounting and Methods}

$\mathrm{CO}_{2}$ removals are treated as fully equivalent to $\mathrm{CO}_{2}$ abatement, not only in how they are defined and used to account for emission targets but also in terms of policy settings. It is therefore seen as a perfectly valid and fungible integrated component of the country's overall mitigation strategy. Other types of CDR are not being seriously discussed. There is growing interest in the farming sector to recognize carbon sequestration in soils, but insufficient science to support adoption of this method. There is a notable absence of serious discussion of BECCS, given the potentially suitable land, coupled with very limited biofuel policies compared to EU countries (Wreford et al., 2019). After several abandoned attempts to introduce price based policies, New Zealand introduced an emissions trading scheme in 2008. In this ETS, $\mathrm{CO}_{2}$ emissions and removals from forestry are treated as fully equivalent to emissions or avoided emissions from gross emitters, to our knowledge the only ETS at national scale to do so. This use of afforestation CDR is consistent with a dominant least-cost principle to climate policy in New Zealand.

\section{Policy Instruments}

This primary price-based policy is complemented by a number of additional government programmes, most recently the One Billion Trees programme that seeks to accelerate forest planting for both climate and non-climate benefits such as erosion control and biodiversity through cash grants and technical support. The Billion Trees programme calls for "the right tree in the right place," reflecting concerns regarding widespread tree monocultures creeping across extensive but productive farmland (Ministry for Primary Industries, New Zealand, 2020). Suggestions are also being made to limit the rate of carbonprice driven afforestation by allowing local government to control plantations using existing environmental (non-climate) legislation. A further point of concern, raised mainly by stakeholders from the agriculture sector, is that New Zealand chose relatively restrictive parameters for what land qualifies as forest and hence can be recognized for afforestation, including a minimum area of 1 hectare and a minimum width of $30 \mathrm{~m}$. Work programmes have been initiated to consider options to recognize the carbon being sequestered in smaller-scale plantings on farmland, especially if agricultural non- $\mathrm{CO}_{2}$ emissions (which 
are currently excluded from climate policy) become exposed to emission prices as currently planned by 2025 .

\section{Expert Bodies and Science}

The integration of CDR into the policy mix has been driven primarily by government officials with support from scientists, in what may be called a technocratic approach to policy development initially (Rimmer, 2016). Policymakers and experts followed the view that "net emissions is what the atmosphere sees." This first-principles lens readily leads to treating carbon removals as fungible with gross emissions. Subsequent scientific criticism of the consequences of this approach (e.g., Parliamentary Comissioner for the Environment, New Zealand, 2019), covering the range of concerns noted above, has not been sufficient to change the overall framework. Impermanence was seen as an insufficient argument against the use of forest sinks, it only indicated the need for policies that provide accountability for subsequent emissions if and when they occurred. The IPCC SR1.5 strongly facilitated the adoption of the net zero target for long-lived gases in New Zealand but did not fundamentally change the CDR policy debate, apart from an increasing recognition of the scale of afforestation and potential for negative side-effects if emissions and removals are priced consistent with that target (Productivity Commission, New Zealand, 2018; Ministry for the Environment, New Zealand, 2019; Parliamentary Comissioner for the Environment, New Zealand, 2019).

\section{Developments in CDR Niches}

As afforestation has a well-established and low-cost role in the policy mix, activity in CDR niches is rather low. Industry interest in CCS exists but is strongly linked with enhanced oil recovery and not seen as industry opening up a more general option to pursue geochemical CDR at scale. Claims and interests in CDR via soil carbon are generally seen as speculative for the near and even medium term, but are the focus of increased government funding for research. This is, however, in part a preparation and insurance for future accounting requirements, not necessarily a goal of developing a new CDR option. While there has been some interest, biofuels policy is limited compared to EU countries (Wreford et al., 2019), and BECCS attracts no significant attention in the national debate.

\section{USA}

\section{Institutional Setting, Actors, and Coalitions}

CDR remains a nascent, yet relatively bipartisan, political issue in the US. National electoral politics in the US, expressed most recently in the 2020 Presidential election, typically focus on the validity of climate change science and modifying the climate policy tools implemented by former-President Barack Obama. Legislatively, most national Democrats (one of two major political parties in the US) are focused on the Trump administration's weakening of environmental regulations, and formation of post-2020 climate policy under a Democratic Biden administration. Early decisions and announcements indicate that CDR will continue to move up the US climate agenda over the coming years. So far, CDR has been discussed in US national politics in two forums: ENGOs, and the Congress.

The US currently has no economy wide emissions target. The new Biden-Harris administration, however, has re-joined the Paris Agreement and will therefore have to provide a new NDC. With regard to a long-term target, the Biden-Harris administration raised expectations toward the adoption of a net zero emissions target in one of the early executive orders (The White House, 2021). The US' first NDC was an economy-wide reduction of GHG emissions by $26-28 \%$ below 2005 levels in 2025. CDR played a relatively small role in this NDC, primarily through inclusion of a robust sink of $\mathrm{CO}_{2}$ in the LULUCF sector. Most US ENGOs, think tanks, trade groups, and philanthropy have been largely supportive of research, development, and deployment of CDR. ENGOs supporting carbon removal have tended to be relatively technology-agnostic, supporting both ecosystem-and geochemical-based methods. A small minority of US ENGOs oppose CDR, primarily "technological" forms of removal such as DACCS. Much of this opposition stems from opposition to CCS as mitigation option for fossil fuel technology. A core area of disagreement between these groups and other ENGOs is whether geochemical-based carbon removal can be a just and progressive form of climate action (Buck, 2019).

\section{CDR Accounting and Methods}

In its first NDC, the US intended to include all categories of emissions by sources and removals by sinks, to account for the LULUCF sector using a net-net approach, and to use a "production approach" to account for harvested wood products consistent with IPCC guidance. Arguments for carbon removal in the US tend to embrace the essential role of carbon removal in achieving climate change goals, technology innovation, sustainable agriculture, and job creation (Energy Futures Initiative, 2019; Friedmann, 2019). These innovation-centric framings span both ecosystem- and geochemical-based CDR methods (Larsen et al., 2019). Relatively few actors promoting CDR have adapted framings around equity and justice, despite its prominence in current US climate policy debates.

\section{Policy Instruments}

CDR has featured prominently in modest climate policy passed between 2016 and 2020. One prominent example of bipartisan legislation is the Agriculture Improvement Act, known commonly as the 2018 Farm Bill. This omnibus bill provides roughly half a trillion dollars in funding for various USDA functions over a period of 5 years through crop insurance, conservation payments, and loan support (Congressional Research Service, 2018). In a departure from historical precedent, the 2018 Farm Bill establishes a variety of new research programs, funding opportunities, and task forces to aid the development and deployment of a wide range of CDR methods. CDR provisions fall into four main titles: (1) Conservation, (2) Research, Extension, and Related Matters, (3) Forestry, and (4) Energy. Within these new provisions, the 2018 Farm Bill supports and incentivizes research on ecosystem-based (soils, forestry, and grazing management), hybrid (bioenergy and 
biogas/renewable natural gas), and geochemical-based (carbon utilization) CDR methods (Jacobson and Sanchez, 2019).

Not explicitly introduced as CDR policy, but relevant for geochemical-based or hybrid methods is the $45 \mathrm{Q}$ tax credit for sequestration of qualified carbon oxides, adopted in 2009. The tax credit is available for 12 years to projects. Several dozen US CCS projects have been announced in part because of the enhanced 45Q tax credit (Clean Air Task Force, 2020), and CDR projects are expected to calculate with the tax credited.

Finally, the Energy Act of 2020, a bipartisan renewable energy bill passed at the end of 2020, contains several provisions to promote CDR. These include establishment of an interagency CDR research program, a prize competition for direct air capture, and allocation of funds for carbon removal, carbon utilization, and carbon sequestration projects. The bill was adopted by bipartisan majorities in both houses of Congress.

Policy instruments to promote CDR have emerged in recent Congressional legislation. These instruments are primarily allocations and appropriations for research and development, and demonstration. Others make small modifications to existing regulations to promote CDR. Such proposals often enjoy bipartisan support in the US, particularly in the Senate. CDR proposals were also included in the platforms of numerous Democrats vying for their party's Presidential nomination in 2020. The platforms prominently emphasized ecosystem-based CDR approaches such as regenerative agriculture. The new administration is expected to follow-up on these and develop new CDR initiatives.

\section{Expert Bodies and Science}

Due to the negative view of the past administration of multilateral fora and scientific expertise on climate change, the IPCC SR1.5 did not play an important role in US climate policy. But the scientific community as well as experts from think tanks and ENGOs are increasingly engaged in CDR debates. As discussed above, most ENGOs in the US have been largely supportive of research, development, and deployment of CDR and contribute to the CDR debate. Prominent themes emphasized include the necessity of CDR in climate action, economic opportunity, and innovation.

\section{Developments in CDR Niches}

Specific deployment opportunities for CDR in the US are still emerging. Nevertheless, deployment prospects are strong due to the US' particular strength in science and engineering, as well as suitable geography for demonstration and early deployment (Sanchez et al., 2018). State level technology and policy opportunities are beginning to materialize at the State and regional scale. Furthermore, start-ups are emerging and prominent technology companies, such as Microsoft and Apple, have made commitments to support and invest in CDR; developments that are likely to be accelerated by the more prominent role for $\mathrm{CDR}$ in the new administration.

\section{SYNTHESIS}

The case studies show the multiplicity and varieties of ways CDR is beginning to be, or already is, part of existing climate policy mixes. Even in these countries-which were selected because they already address the $\mathrm{CDR}$ in some form-considerable differences in the pace and forms of acknowledging and governing CDR are observed. While CDR policy has already been adopted in some cases for quite some time, in others it is currently being shaped by political positioning of different actors. In order to identify differences and patterns of CDR policy making, we organize the synthesis along the five dimensions of the analytical framework presented in Table 1. Based on these findings, we develop a conceptual typology of the observed varieties and patterns. It is our intention that the contribution of a first attempt of organizing current developments into a conceptual frame will spur work on more fine-grained comparisons and prospects for CDR policy.

\section{Institutional Setting, Actors, and Coalitions}

In all nine case studies, climate policy is a well-institutionalized policy domain with clearly-defined actors, political positions and path-dependencies. The countries differ, however, in the ambition and design of emissions reduction targets. They also choose different policy instruments and measures to achieve their commitments. It can be observed that net zero targets-which began to diffuse into domestic climate politics after the macropolitical changes of the adoption of the Paris Agreement and the IPCC SR1.5-facilitated or gave new importance to CDR debates. Australia and the US are the only countries in this selection that do not currently (January 2021) have a formally adopted net zero emissions target of some kind at national level.

The existing net zero targets differ substantially in their scope and timing. Whereas most countries address all GHG emissions, New Zealand for example, excludes biogenic methane from its net zero ambition. Questions of target design have a significant impact on the amount of residual emissions that need to be balanced by CDR to achieve net zero (McLaren et al., 2019; Fridahl et al., 2020), and are therefore an important overarching dimension of CDR policies.

\section{Between Highlighting and Kicking off CDR Policies After the Paris Agreement}

The developments in Australia, the UK, and New Zealand show that domestic climate policies aiming at deliberately balancing emissions with removals to achieve mitigation targets is not only a post-Paris development. Although pre-Paris CDR policies were not directly framed as a tool to compensate for residual gross emissions, they aimed at incentivising different actors to enhance the LULUCF sink to help achieve mitigation targets at lower costs. In these countries, the Paris Agreement brought new attention to an already existing strand of climate policy. In the other cases, the emergence of CDR policies is closely connected with the macro-political change represented by the Paris Agreement. Here, CDR in the pre-Paris era was, if at all, regulated implicitly. Public policy on explicitly regulating and incentivising additional removals and accounting them toward 
domestic mitigation targets only kicked off in connection with or in the aftermath of adopting net zero targets.

\section{Business and Industry}

The positioning and engagement of business and industry actors reflects the variety of current status and prospects of CDR in each country. In cases where the LULUCF sinks are already routinely counted toward mitigation targets, the forestry and to some extent agriculture sector generally supports the use of ecosystem-based CDR (i.e., New Zealand, the UK, and Australia), as well as existing or new initiatives to reward CDR. In the UK and the US, geochemical-based CDR methods are getting increasing attention by business actors. Also in Sweden and Ireland, the business sector is generally in support of the recent domestic CDR initiatives; some actors are directly involved in exploring business cases and actual deployment. Whereas businesses in Ireland are focused on ecosystembased methods, Swedish companies are involved in a wider range of CDR approaches. In Norway, the fossil and energyintensive industries are, supported by the government, engaged in deploying and promoting a CCS infrastructure relevant for durably storing domestic and imported $\mathrm{CO}_{2}$ that could support a future expansion of geochemical-based CDR. In Germany, the industry is rather reluctant with regard to CDR; early collaborations between industry and CDR companies, however, signal a potential change.

\section{Environmental Non-Governmental Organizations}

How ENGOs approach CDR policy also differs significantly and can be conceptualized as a continuum between suspicion and agnosticism. In the EU and its Member States, their position is primarily driven by suspicion that integrating CDR in the climate regime obstructs necessary changes to reduce gross emissions. Although the need for CDR is increasingly accepted and addressed by ENGOs, geochemical-based methods are a particular source of concern. In the US, ENGOs are mostly technology-agnostic, some support geochemical-based CDR proactively. In New Zealand, Norway, and the UK, the picture is rather mixed; whereas some ENGOs are skeptical especially of geochemical-based CDR or approaches that threaten biodiversity, others do acknowledge the need for CDR. In New Zealand, civil society also highlights a rural/urban conflict; rural communities are critical of the idea that they should live with the socio-economic consequences of land-use change to balance ongoing emissions caused in cities. In Australia, ENGOs have not engaged substantially nor explicitly on CDR.

\section{CDR Accounting and Methods}

The accounting of CDR varies between full equivalence and reluctance to aggregate emissions and removals. In Australia, New Zealand, and the UK, LULUCF removals are regarded as fungible ${ }^{8}$ with gross emissions to achieve climate targets. There is currently no cap on the amount of removals that can be used to achieve the domestic targets. This is in contrast to the EU and

\footnotetext{
${ }^{8}$ We use the term "fungible" to express that CDR and emissions reduction are interchangeable and mutual substitutes in accounting practices of mitigation targets.
}

Norway, where policymakers have so far been rather reluctant to account for large shares of LULUCF sinks toward their mitigation targets. Recent policy initiatives, however, are inducing change. At the Member State level, Sweden has adopted a net zero target with two components: a minimum amount of emissions reductions and maximum amount of CDR in combination with international offsets, so-called supplementary measures. In Ireland, land use sinks were tacitly used to balance emissions from ruminant agriculture, but emerging climate legislation gives new and more explicit importance to removals. Germany has not pursued efforts to integrate removals in their mitigation target, but a net target at EU-level would affect German accounting practices as well.

\section{Differentiating CDR Methods}

Different CDR methods attract varying degrees of attention in the analyzed set of countries. While specific definitions and attribution of methods to categories of "natural" and "technological" methods are contingent and in flux, the general distinction shapes the public policy processes and societal debates in all cases. In the UK, Sweden, and Norway geochemical-based methods are proactively addressed, as in Australia and the US though to a more limited extent. In Germany, all methods that include CCS are highly contested in the societal debate. At the EU level, a need for geochemical-based CDR is acknowledged by the European Commission, but the policy initiatives announced so far focus on ecosystem-based CDR. All eight case studies have policy debates or pursue initiatives linked to ecosystem-based CDR in one way or the other, especially afforestation.

\section{The Changing Political Status of Forestry}

The comparison across the cases indicates that the role of forestry in climate policy is changing, a change facilitated by integrating CDR into climate policy. The countries differ in the degree to which forestry is accounted toward climate targets. Especially in those countries that aggregate emissions and removals and account for the forest sink in mitigation targets, forestry and its capacity to remove $\mathrm{CO}_{2}$ is a key component of climate policy. Other countries, like the EU and its Member States, for example, just launched political initiatives for considering the full LULUCF sink in the context of their mitigation targets and thereby give new importance to forestry in climate policy making. In line with recent findings on the history of carbon removal (Carton et al., 2020) and a review of policy tools (vonHedemann et al., 2020) we find that the political status of the LULUCF sink, and forestry in particular, has changed with the emergence of CDR policies, legitimizing the use of LULUCF in some countries while raising questions about the scale and practices of afforestation in others. Future work on CDR policy should therefore analyze the political drivers and implications of these shifts.

\section{Policy Instruments: Between Trading, Rewarding, and R\&D}

The comparison of CDR-related policy instruments reveals three key groups. The first consists of different policy approaches for mitigation instruments that fully integrate removals. Examples of this are the Australian reverse auction scheme under the 
Emissions Reduction Fund, or the emission trading scheme in New Zealand, that treat emissions and removals as fully equivalent. With its separate net zero target, Sweden is a special case: its policies to incentivize and instigate deployment of geochemical-based and ecosystem-based CDR are structurally linked to the overall climate target, but are largely independent from conventional mitigation policies.

A second group of instruments is composed of rewarding schemes to incentivize CDR, which are not directly linked to or integrated with climate policy instruments targeting conventional mitigation. Examples are the Woodland Carbon Guarantee in the UK, or the US 45Q Tax Credit. Incentive structures aiming to enhance the LULUCF sink through afforestation or rewetting of drained peatlands outside emissions pricing policies are also established in New Zealand, Norway, Ireland, and Sweden. In Norway and the UK, the efforts to establish a CCS infrastructure by industry and political actors are increasingly framed as CDR-relevant, although questions of their actual accounting are not yet decided. In general, it can be observed that already existing non-integrated instruments targeting CDR received substantially more attention after the adoption of the Paris Agreement than before. In addition, many new initiatives and policy instruments were proposed and adopted since then.

A third group of policy instruments contains R\&D funding initiatives that mostly target geochemical-based CDR approaches. However, as mentioned above, definitions of CDR are in flux-especially in the context of researching new approaches. One major difference across the cases is the degree to which the research funding targets deployment of geochemical-based CDR. In the UK, Sweden, and Australia, research funding targets a wide range of CDR approaches, including funds for demonstration and deployment of the geochemical-based methods. The EU Innovation Fund and Norway's support for CDR-related R\&D in the context of CCS infrastructure are pointing in a similar direction. CDR research is also part of a large Farming Bill adopted in 2018 in the US. The US supports and incentivizes research on a broad portfolio of CDR methods. R\&D as well as demonstration and deployment funding is expected to increase substantially in the coming years. Similarly, in Germany, the government decided to create two large CDR research funding lines from 2021 onwards-deployment, however, is not a specific objective here.

\section{The Role of Experts and Science}

In all case studies, scientific expertise is important for initiating and developing CDR policies. CDR entered the public policy decision making processes through a rather technocratic approach. Scientific experts and specialized policymakers in the administrations have been key actors in pursuing CDR integration. The public debate is-compared to other climate policy related issues-almost non-existent except where it is linked with wider land management practices. The IPCC's SR1.5 and follow-up publications by national science advisory bodies in particular, however, elevated the issue of CDR on the agenda of think tanks, policymakers, NGOs etc.
National modeling studies increasingly address possible compositions of mid-century residual emissions and the amounts and types of CDR required to balance them. The need for at least some countries to achieve domestic net-negative GHG emissions, however-a necessary part of Paris Agreement's global long-term temperature target of well below $2^{\circ} \mathrm{C}$ while pursuing $1.5^{\circ} \mathrm{C}-$ is still only addressed by small groups of scientific experts and narrow policy circles. Despite the fact that OECD countries can be argued to have a particular responsibility for achieving netnegative emissions (Robiou Du Pont et al., 2017; Fyson et al., 2020; Pozo et al., 2020), the issue is only rarely and briefly addressed in emerging policy initiatives and could be argued to be actively disabled by a focus on net zero emission targets.

\section{Developments in CDR Niches}

Developments in the niches range from very small start-up initiatives with low support to proactive support for large CDR initiatives by industrial actors. Across the case study countries, we observe very different actors engaged in the protective spaces of CDR development. Among them: energy sector companies in the UK and Sweden, fossil fuel, and energy-intensive industries in Norway, and start-ups in Australia, the US and the UK. The niches are protected in various ways and to different degrees: Most prominently, the UK support for innovation exemplifies how a government tries to strategically position itself as a frontrunner and technology-provider. In Norway, the government also proactively supports innovations in CDRrelated initiatives, both in terms of developing, but also politically in the form of advocating the EU to support export of $\mathrm{CO}_{2}$ to Norway. Together with Sweden, where especially innovations in and deployment of BECCS are supported by the government, this group of countries engage in "nurturing" and "empowering" (Smith and Raven, 2012) CDR development and deployment. In the other countries, niche developments are not supported in such a proactive way but are generally limited to incentives or research funding. However, in New Zealand for example, path-dependent reliance on incumbent CDR regimes can actively reduce incentives to invest in the proactive development of additional CDR approaches.

\section{VARIETIES OF INTEGRATING CDR INTO CLIMATE POLICY: TOWARD A TYPOLOGY}

The synthesis provided an overview of the varieties of CDR policymaking in the countries. While the peculiarities of individual cases became particularly clear, in a second step we are attempting to identify broader patterns of CDR policy making and develop an analytical typology. In doing so, we follow the MLP of socio-technical transitions, where identifying typologies of transitions is a common tool to conceptualize commonalities and differences across case studies (Smith et al., 2005; Geels and Schot, 2007; Geels et al., 2016). This work is an important reminder of the fact that transitions are not "teleological or deterministic, but continuously enacted by and contested between a variety of actors" (Geels et al., 2016, p. 900). Shifts between different types are of course possible (Geels 
et al., 2016), for example, if societal power structures and political alliances change (Hess, 2014).

In a first step of conceptualizing our findings, we propose five key dimensions to aggregate varieties of CDR policymaking. Each dimension represents a continuum of manifestations that we identified across the cases (see Table 2). It is important to note that these continua are drawn from the synthesis of case studies, and we do not intend for them to represent a definitive nor exhaustive coverage of all possible CDR policy making dynamics. However, we believe these are a useful representation as a first step to carve out differences and commonalities between political approaches toward CDR and therefore a useful step to develop a typology of CDR policymaking that may enable future comparative analysis of other countries and across policy domains and support analysis of change in CDR policy making dynamics over time.

In a second step, we use the five dimensions and continua to build a three-tiered typology on how CDR is currently being addressed and integrated in climate policy regimes. The types are idealized; differences are deliberately overstated in order to support analytical clarity ${ }^{9}$. Their main utility is to illustrate divergent possible policy approaches toward CDR that we observed in the case studies. Based on the continua observed in the case studies, we attempt to identify the conceptually most distinctive types of how CDR is approached. In reality, countries might lean to one or the other type, but do not necessarily match all typical characteristics or may represent hybrids. In actual CDR policymaking, boundaries are blurry and overlaps exist. Furthermore, shifts between the different types and developing new types is possible over time; discussions about which direction to follow in CDR policymaking is expected to be politically contested. Identifying these conceptual types is, however, a way of further synthesizing the knowledge gathered through empirical case studies. It may inform future comparative work on CDR policy as well as spur a debate about possible and plausible developments in future CDR policy. These types are not formulated as a finite result. Future work, e.g., on a different set of countries might identify important amendments and additions to this typology.

Table 3 and Figure 1 provide an overview of the three conceptual types of CDR policymaking; the following sections describe the three types in more detail and give an overview of

\footnotetext{
${ }^{9}$ Identifying typologies has a long tradition in social science more generally. For a discussion of methodological merits and criticisms in political science, see e.g., Steinberger (1980), Smith (2002), Elman (2005), Collier et al. (2012).
}

typical cases and hybrid forms of CDR policy approaches among the cases.

\section{Incremental Modification: Limited Integration of CDR}

The type of incremental modification is shaped by a restrained approach toward integrating CDR into existing climate policy instruments to address the need to balance residual emissions. These incremental steps to integrate CDR are shaped by rather strict separations between emission reductions and removals in the accounting toward mitigation targets. CDR policies and policy instruments linked to conventional mitigation are also strictly separated. Over time, the incremental opening could lead to an advancing integration of removal and reduction instruments.

Incumbent actors do not ignore the need for CDR completely; in particular, macro-political developments toward the new importance of sinks puts pressure on the climate policy regime. In this context, their incremental approach leads to a step by step integration of ecosystem-based CDR approaches. With regard to policy instruments, a cautious opening toward CDR is characteristic for this type, allowing for accounting of a limited amount of ecosystem-based CDR. Regarding geochemical-based CDR, the focus is on RD\&D. Support for new CDR methods in small niches and their deployment, however, is limited; research funding is the only support for them.

\section{Early Integration and Fungibility of Emission Reductions and Removals}

In this type, CDR is already part of the climate policy regime. Even before macro-political developments such as the Paris Agreement and the diffusion of long-term net zero targets, fungibility of emissions and removals was established. Established policies reflect the assumption that "net emissions is what the atmosphere sees." Since the Paris Agreement, incumbent actors give more attention toward CDR; policymakers and other actors are now exploring options to foster and expand CDR's role in achieving long-term goals.

This type is characterized by the fact that ecosystem-based removals are fully integrated in policy instruments such as emission trading schemes or reverse auctions. Geochemicalbased CDR would-from a sheer regulatory point of view-be comparatively easy to integrate, especially because the share of CDR that can be used to achieve climate targets is not limited in this type. Because CDR approaches are already part of a stable

TABLE 2 | Five dimensions of CDR policy making and continua of observed manifestations.

Dimensions

CDR in mitigation targets

View of CDR among actors of the incumbent regime

CDR methods addressed

Relation of CDR policy instruments to broader climate policy mix

Government support for developing CDR niches

Continua

Fungible

Proactive integration

Only ecosystem-based

Incremental opening

Limited support

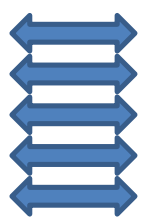

Strictly separated

Restrained integration

Wide range of methods

Full integration

Nurturing and empowering 
TABLE 3 | Three types of integrating CDR into climate policy.

\begin{tabular}{|c|c|c|c|}
\hline & $\begin{array}{l}\text { I. Incremental } \\
\text { modification }\end{array}$ & $\begin{array}{l}\text { II. Early integration and } \\
\text { fungibility }\end{array}$ & $\begin{array}{l}\text { III. Proactive CDR } \\
\text { entrepreneurship }\end{array}$ \\
\hline CDR in mitigation targets & Strictly separated & Fungible & Fungible \\
\hline View of CDR among actors of the incumbent regime & Restrained integration & Proactive integration & Proactive integration \\
\hline CDR methods addressed & Ecosystem-based only & Focus on ecosystem-based & Proactive technology support \\
\hline Relation of CDR policy instruments to broader climate policy mix & Incremental opening & Full integration & Specific instruments \\
\hline Government support for developing CDR niches & Limited support & Limited support & Nurturing and empowering \\
\hline
\end{tabular}

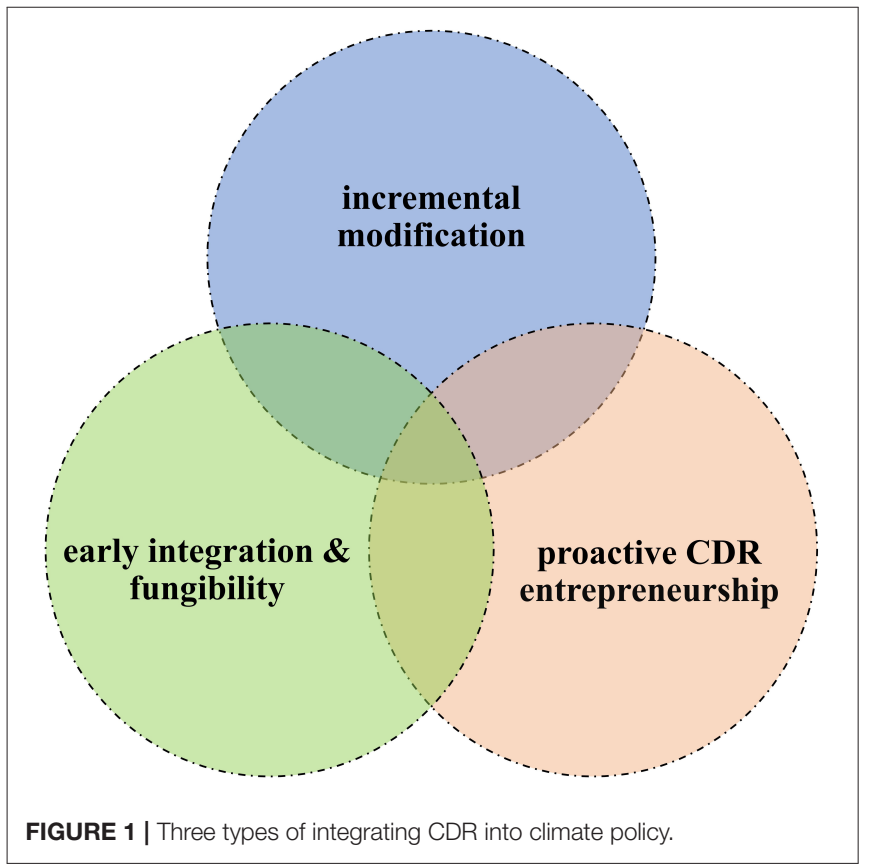

climate policy regime and macro-political changes did not put pressure on the regime in countries of this type, developments in niches and their support is not very pronounced.

\section{Proactive CDR Entrepreneurship}

The political envisioning of a net zero emissions society is directly linked to the deployment of CDR in the type of proactive CDR policy entrepreneurship ${ }^{10}$. The incumbent actors address the need to integrate and deploy CDR and pursue the reorientation and opening-up of current conventional mitigation climate policies proactively. In comparison to other types, niches of radical geochemical-based CDR innovations are deliberately nurtured and empowered. In general, CDR policy is open to a wide range of CDR methods.

In contrast to the early integration type, CDR-specific policy instruments are being developed (e.g., reverse auction or financial rewarding schemes) which are not fully integrated into conventional mitigation policy instruments. This is not only because of path-dependencies created by existing policy

\footnotetext{
${ }^{10}$ The term "policy entrepreneur" describes "their willingness to invest their resources-time, energy, reputation, and sometimes money-in the hope of a future return" in public policy making Kingdon (1995, p. 122).
}

instruments, but also because incumbent actors follow the objective of supporting the CDR development and deployment specifically. Being perceived as a frontrunner in changing macropolitical contexts as well as a technology provider through developing and deploying CDR technologies and exploring business cases is one of the political objectives of the incumbent actors in this third idealized type of CDR policymaking.

\section{Typical Cases and Hybrids}

If we try to locate our case studies on this spectrum of varieties of CDR policy making, they can be differentiated between typical cases and hybrids. The UK can be described as a typical case for the type of proactive CDR policy entrepreneurship. None of the other countries studied have such explicit policy support for the development and deployment of various CDR measures. To a limited extent, policy entrepreneurship can also be identified in the European Union. However, the initiatives come mainly from within the European Commission; only the coming years will show how the Member States position themselves. Within the EU, Sweden is the country with the most specific and advanced CDR policy and shows policy entrepreneurship. Its regulative approach of separating reductions and removals as well as long-lasting debates on LULUCF removals, however, indicate overlaps to the types of incremental modification as well as early integration and fungibility. In Norway, we observe policy entrepreneurship with regard to CCS, a key component of several geochemical CDR approaches. Initiatives for specific CDR policies, however, are so far limited and emerging only incrementally. The new US administration is expected to establish and develop specific CDR policies in the coming years. With respect to geochemical-based CDR in particular, the US is signaling that it is striving to be perceived and act as a frontrunner.

Australia and New Zealand are typical cases for the early integration and fungibility type. Both integrated CDR into their domestic policy before the recently rising attention toward these measures. In addition, both policy-designs are shaped by fungibility of emissions and removals. Some aspects of this type are also to be found in the case study of Ireland. At the same time, however, we also observe aspects of incremental modification in Ireland. Germany is a typical case for this third type of incremental modification. Although actual integration of CDR into the climate policy mix is almost absent so far, the societal and political debate is increasingly opening toward CDR.

It is important to highlight that this assessment can only be a snapshot. How CDR is approached politically is currently 
contested and will be subject to political struggles in the future. Future work on comparing CDR policy approaches should therefore not only extend the list of countries but also assess how the countries initially studied for this project are developing. The cases identified as hybrids are of particular interest-an in-depth analysis of the dynamics currently taking place, including the opportunity to reveal emerging new political approaches to CDR, would be an important contribution to the emerging literature on CDR.

\section{CONCLUSIONS}

In our analysis of nine empirical case studies we analyzed the varieties of CDR policymaking and provide a snapshot of a rapidly developing policy field. Based on the analytical framework that tries to bridge insights from the multi-level perspective on socio-technical transitions and the emerging literature on CDR policy and governance, we tracked the developments across these cases. The synthesis of this rich empirical material reveals substantial differences as well as commonalities across the cases. In an attempt to conceptualize different patterns of CDR policymaking, we identified five dimensions of CDR policymaking and proposed three idealized types of CDR policy making: (1) incremental modification, (2) early integration and fungibility, and (3) proactive CDR policy entrepreneurship.

It is important to note that boundaries of these idealized types are blurry; in the real-world, specific cases do not necessarily match all characteristics of one type and hybrids exist. In addition, countries can shift between different types over time and new types might emerge. Such an evolution is expected not only because policies and approaches are expected to evolve, but also because CDR policies are contested as political actors struggle for different prospects of governing CDR. These drivers are capable of re-directing current developments in CDR policymaking toward different or entirely new types of CDR policy and governance.

\section{REFERENCES}

Anderson, K., and Peters, G. P. (2016). The trouble with negative emissions. Science 354, 182-183. doi: 10.1126/science.aah4567

Australian Academy of Science (2018). 2018 Negative Emissions Conference: The Big Picture of Negative Emissions. Available online at: https:// www.science.org.au/news-and-events/events/2018-negative-emissionsconference-big-picture-negative-emissions (accessed January 24, 2021).

Australian Government (2020). Australian Government Response to the Final Report of the Expert Panel Examining Additional Sources of Low-Cost Abatement ('the King Review'). Available online at: https://www.industry.gov. $\mathrm{au} /$ data-and-publications/government-response- to- the-expert-panel-reportexamining-additional-sources-of-low-cost-abatement (accessed January 24, 2021).

Aykut, S. C., d'Amico, E., Klenke, J., and Schenuit, F. (2020). The Accountant, the Animator, and the Admonisher: Global Climate Governance in Transition. Report From the COP25 Climate Summit in Madrid. CSS Working Paper Series No 1. Hamburg: Center for Sustainable Society Research. doi: $10.25592 /$ css-wp-001
The proposed conceptualization helps to synthesize the knowledge collected through the case studies and illustrates divergent possible approaches. As a conceptual typology, however, it is reductionist and does not cover all dimensions relevant to regulating CDR. Despite these limitations, this initial work on comparing CDR policymaking and conceptualizing different analytical types might spur future, more finegrained work, including comparing different sets of countries, investigating in-depth single case studies and tracking changes in CDR policymaking over time.

\section{AUTHOR CONTRIBUTIONS}

FS conceptualized the research with contributions from OG. FS drafted the manuscript for sections Introduction, Synthesis, Varieties of integrating CDR into climate policy: Toward a typology, and Conclusions. FS, OG, BM, MF, AT, SS, BC, AR, $\mathrm{AW}$, and DS provided the case studies. All authors revised and improved the manuscript.

\section{FUNDING}

This work was supported by Deutsche Forschungsgemeinschaft (DFG, German Research Foundation) under Germany's Excellence Strategy-EXC 2037 CLICCS-Climate, Climatic Change, and Society [Project Number: 390683824]; the Swedish Energy Agency [Grant nos. 46222-1, 46036-1, and 51569-1], the Swedish Research Council Formas [Grant nos. 2019-01993, and 2019-01973], the Research Council of Norway [Grant no. 295789].

\section{ACKNOWLEDGMENTS}

Thanks to Stefan Aykut, Megan C. Evans, Erlend Andre T. Hermansen, Helen Plume, and Bruno Turnheim for valuable comments. The Norwegian Environment Agency has provided information on Norway's climate policies.

Azar, C., Lindgren, K., and Persson, T. (2001). Carbon Sequestration From Fossil Fuels and Biomass - Long-Term Potentials. Second Nordic Mini Symposium on Carbon Dioxide Capture and Storage, Gothenburg. Available online at: http://www.entek.chalmers.se/\$sim\$anly/symp/01azar.pdf (accessed January 24, 2021).

Bataille, C. G. F. (2020). Physical and policy pathways to net-zero emissions industry. WIREs Clim. Change 11:e633. doi: 10.1002/wcc.633

Beck, S., and Mahony, M. (2018). The politics of anticipation: the IPCC and the negative emissions technologies experience. Glob. Sustain. 1:e8. doi: $10.1017 /$ sus.2018.7

Bellamy, R., Fridahl, M., Lezaun, J., Palmer, J., Rodriguez, E., Lefvert, A., et al. (2021). Incentivising bioenergy with carbon capture and storage (BECCS) responsibly: comparing stakeholder policy preferences in the United Kingdom and Sweden. Environ. Sci. Policy. 116, 47-55. doi: 10.1016/j.envsci.2020. 09.022

Bellamy, R., Lezaun, J., and Palmer, J. (2019). Perceptions of bioenergy with carbon capture and storage in different policy scenarios. Nat. Com. 10:743. doi: 10.1038/s41467-019-08592-5

Bellamy, R., and Osaka, S. (2020). Unnatural climate solutions? Nat. Clim. Chang. 10, 98-99. doi: 10.1038/s41558-019-0661-z 
Böttcher, H., Zell-Ziegler, C., Herold, A., and Siemons, A. (2019). EU LULUCF Regulation Explained: Summary of Core Provisions and Expected Effects. Berlin: Öko-Institut. Available online at: https://www.oeko.de/fileadmin/oekodoc/ Analysis-of-LULUCF-Regulation.pdf (accessed January 24, 2021).

Buck, H. J. (2016). Rapid scale-up of negative emissions technologies: social barriers and social implications. Clim. Change 139, 155-167. doi: 10.1007/s10584-016-1770-6

Buck, H. J. (2019). After Geoengineering: Climate Tragedy, Repair, and Restoration. London, Brooklyn, NY: Verso.

Bundesgesetzblatt (2019). Gesetz zur Einführung eines Bundes-Klimaschutzgesetzes. Part I Nr. 48, 2513-2521. Available online at: http://www.bgbl.de/xaver/ bgbl/start.xav?startbk=Bundesanzeiger_BGBl\&jumpTo=bgbl119s2513.pdf (accessed January 24, 2021).

Bundesministerium für Bildung und Forschung (2020a). Richtlinie zur Förderung von Forschungs- und Entwicklungsvorhaben im Rahmen des Forschungsprogramms der Bundesregierung MARE:N - Küsten-, Meeres- und Polarforschung: Forschungsmission "Marine Kohlenstoffspeicher als Weg zur Dekarbonisierung" der Deutschen Allianz Meeresforschung. Available online at: https://www.bmbf.de/foerderungen/bekanntmachung-3017.html (accessed January 24, 2021).

Bundesministerium für Bildung und Forschung (2020b). Richtlinie zur Förderung von Projekten zum Thema "Methoden zur Entnahme von atmosphärischem Kohlendioxid (Carbon Dioxide Removal)". Available online at: https:// www.bmbf.de/foerderungen/bekanntmachung-3047.html (accessed January 24, 2021).

Bundesministerium für Wirtschaft und Energie (2020). German Integrated National Energy and Climate Plan. Available online at: https://ec.europa. eu/energy/sites/ener/files/documents/de_final_necp_main_en.pdf (accessed January 24, 2021).

Burke, P. J. (2016). Undermined by adverse selection: Australia's direct action abatement subsidies. Econ. Pap. 35, 216-229. doi: 10.1111/1759-3441.12138

Carbon Abatement Panel (2020). Report of the Expert Panel Examining Additional Sources of Low Cost Abatement. Available online at: https://apo.org.au/sites/ default/files/resource-files/2020-05/apo-nid305063.pdf (accessed January 24, 2021).

Carson, M., Burns, T., and Calvo, D. (eds.) (2010). Paradigms in Public Policy: Theory and Practice of Paradigm Shifts in the EU. Frankfurt a.M.: Peter Lang. doi: 10.3726/978-3-653-01189-0

Carton, W., Asiyanbi, A., Beck, S., Buck, H. J., and Lund, J. F. (2020). Negative emissions and the long history of carbon removal. WIREs Clim. Change 11:e671. doi: 10.1002/wcc.671

Chan, G. (2018). Rusted Off: Why Country Australia is Fed Up. Sydney, NSW: Vintage Australia.

Clean Air Task Force (2020). Potential Carbon Capture Projects Database. Available online at: https:/docs.google.com/spreadsheets/ d/115hsADg3ymy3lKBy4PBQRXz_MBknptqlRtlfuv79XV8/edit\#gid= 1540463113 (accessed January 24, 2021)

Climate Action Network (2018). Position Paper on Forest and Land Restoration Natural Ways of Limiting Temperature Rise to Below $1.5^{\circ} \mathrm{C}$. Available online at: http://www.climatenetwork.org/sites/default/files/can_land_and_forest_ position_final.pdf (accessed January 24, 2021).

Climate Assembly UK (2020). The Path to Net Zero. Available online at: https:// www.climateassembly.uk/report/read/final-report.pdf (accessed January 24, 2021).

Climate Change Advisory Council (2019). Advice on a Suitable Approach for Preparation of Multi-Annual Carbon Budgets to Inform Preparation of Drafting of Legislation. Available online at: https://www.climatecouncil.ie/media/ climatechangeadvisorycouncil/contentassets/publications/Carbon\%20Budget \%20Background\%20paper.pdf (accessed January 24, 2021).

Climate Change Advisory Council (2020). Annual Review 2020. Available online at: https://www.climatecouncil.ie/media/climatechangeadvisorycouncil/ contentassets/publications/CCAC_AnnualReview2020FINAL.pdf (accessed January 24, 2021).

Climate Council (2020). What Does Net Zero Emissions Mean? Available online at: https://www.climatecouncil.org.au/resources/what-does-net-zeroemissions-mean/ (accessed December 6, 2020).

Cointe, B., Cassen, C., and Nadai, A. (2019). Organising policy-relevant knowledge for climate action: integrated assessment modelling, the IPCC, and the emergence of a collective expertise on socioeconomic emission scenarios. Sci. Technol. Stud. 32, 36-57. doi: 10.23987/sts.65031

Collier, D., LaPorte, J., and Seawright, J. (2012). Putting typologies to work. Political. R. Q. 65, 217-232. doi: 10.1177/1065912912437162

Colvin, R. M., Kemp, L., Talberg, A., De Castella, C., Downie, C., Friel, S., et al. (2020). Learning from the climate change debate to avoid polarisation on negative emissions. Environ. Commun. 14, 23-35. doi: 10.1080/17524032.2019.1630463

Committee on Climate Change (2016). UK Climate Action following the Paris Agreement. Available online at: https://www.theccc.org.uk/wp-content/ uploads/2016/10/UK-climate-action-following-the-Paris-Agreement-

Committee-on-Climate-Change-October-2016.pdf (accessed January 24, 2021).

Committee on Climate Change (2019). Net Zero: The UKs Contribution to Stopping Global Warming. Available online at: https://www.theccc.org.uk/ publication/net-zero-the-uks-contribution-to-stopping-global-warming/ (accessed January 24, 2021).

Committee on Climate Change (2020). Sixth Carbon Budget Report. Available online at: https://www.theccc.org.uk/publication/sixth-carbon-budget/ (accessed January 24, 2021).

Congressional Research Service (2018). Agriculture and Related Agencies: FY2018 Appropriations. CRS Report, R45128. Available online at: https://fas.org/sgp/ crs/misc/R45406.pdf (accessed January 24, 2021).

Cox, E., and Edwards, N. R. (2019). Beyond carbon pricing: policy levers for negative emissions technologies. Clim. Policy 19, 1144-1156. doi: 10.1080/14693062.2019.1634509

Cox, E., Spence, E., and Pidgeon, N. (2020). Public perceptions of carbon dioxide removal in the United States and the United Kingdom. Nat. Clim. Chang. 10, 744-749. doi: 10.1038/s41558-020-0823-Z

Crowley, K. (2017). Up and down with climate politics 2013-2016: the repeal of carbon pricing in Australia. WIREs Clim. Change 8:e458. doi: 10.1002/wcc.458

Davis, S. J., Lewis, N. S., Shaner, M., Aggarwal, S., Arent, D., Azevedo, I. L., et al. (2018). Net-zero emissions energy systems. Science 360:eaas9793. doi: $10.1126 /$ science.aas 9793

Den Elzen, M., den, Kuramochi, T., Höhne, N., Cantzler, J., Esmeijer, K., Fekete, $\mathrm{H}$., et al. (2019). Are the G20 economies making enough progress to meet their NDC targets? Energy Policy 126, 238-250. doi: 10.1016/j.enpol.2018. 11.027

Department of Industry, Science, Energy and Resources, Australia (2020a). Methods for the Emissions Reduction Fund. Available online at: https://www. industry.gov.au/regulations-and-standards/methods-for-the-emissionsreduction-fund (accessed January 24, 2021).

Department of Industry, Science, Energy and Resources, Australia (2020b). Quarterly Update of Australia's National Greenhouse Gas Inventory: March 2020. Available online at: https:/www.industry.gov.au/data-and-publications/ national-greenhouse-gas-inventory-march-2020 (accessed January 24, 2021).

Department of Industry, Science, Energy and Resources, Australia (2020c) Technology Investment Roadmap: First Low Emissions Technology Statement. Available online at: https://www.industry.gov.au/sites/default/files/September $\% 202020 /$ document/first-low-emissions-technology-statement-2020.pdf (accessed January 24, 2021)

Deutscher Naturschutz Ring (2020). Von Worten zu Taten: Für ein Pariskompatibles EU-Klimaschutzgesetz. Available online at: https://www.dnr.de/ fileadmin/Positionen/2020-05-05-EU-Klimaschutzgesetz-Verbaendeposition. pdf (accessed January 24, 2021).

Dooley, K., Harrould-Kolieb, E., and Talberg, A. (2020). Carbon-dioxide removal and biodiversity: a threat identification framework. Glob. Policy. 1-11. doi: $10.1111 / 1758-5899.12828$

Dunne, D. (2018). Negative Emissions Scientists Meet in Australia to Discuss Removing CO2 From the Air. Carbon Brief, 1 Nov. Available online at: https:// www.carbonbrief.org/negative-emissions-scientists-meet-in-australia-todiscuss-removing-co2-from-air (accessed January 24, 2021).

Dütschke, E., Wohlfarth, K., Höller, S., Viebahn, P., Schumann, D., and Pietzner, K. (2016). Differences in the public perception of CCS in Germany depending on CO 2 source, transport option and storage location. Int. J. Greenh. Gas Control 53, 149-159. doi: 10.1016/j.ijggc.2016.07.043

Elman, C. (2005). Explanatory typologies in qualitative studies of international politics. Int. Org. 59, 293-326. doi: 10.1017/S0020818305050101 
Energy Futures Initiative (2019). Clearing the Air: A Federal RD心D Initiative and Management Plan for Carbon Dioxide Removal Technologies. Report. Available online at: https://www.ourenergypolicy.org/resources/clearing-theair-a-federal-rdd-initiative/ (accessed January 24, 2021).

European Commission (2018). In-Depth Analysis in Support of the Commission Communication COM(2018) 773. A Clean Planet for all - A European Long-Term Strategic Vision for a Prosperous, Modern, Competitive and Climate Neutral Economy. Available online at: https://ec.europa.eu/clima/ sites/clima/files/docs/pages/com_2018_733_analysis_in_support_en_0.pdf (accessed January 24, 2021).

Evans, M. C. (2018). Effective incentives for reforestation: lessons from Australia’s carbon farming policies. Curr. Opin. Environ. Sustain. 32, 38-45. doi: 10.1016/j.cosust.2018.04.002

Fajardy, M., Patrizio, P., Daggash, H. A., and Mac Dowell, N. (2019). Negative emissions: priorities for research and policy design. Front. Clim. 1:6. doi: $10.3389 /$ fclim.2019.00006

Fridahl, M. (2017). Socio-political prioritization of bioenergy with carbon capture and storage. Energy Policy 104, 89-99. doi: 10.1016/j.enpol.2017.01.050

Fridahl, M. (2018). (ed.). Bioenergy With Carbon Capture and Storage: From Global Potentials to Domestic Realities. Brussels: European Liberal Forum.

Fridahl, M., Hansson, A., and Haikola, S. (2020). Towards indicators for a negative emissions climate stabilisation index: problems and prospects. Climate 8:75. doi: $10.3390 /$ cli8060075

Friedmann, S. J. (2019). Engineered CO2 removal, climate restoration, and humility. Front. Clim. 1:3. doi: 10.3389/fclim.2019.00003

Friends of the Earth (2018). A Pathway to 'net zero' Greenhouse Gas Emissions. Briefing. Available online at: https://cdn.friendsoftheearth.uk/sites/default/ files/downloads/Pathway-net-zero-greenhouse-gas-emissions-UK.pdf (accessed January 24, 2021).

Fuss, S., Canadell, J. G., Ciais, P., Jackson, R. B., Jones, C. D., Lyngfelt, A., et al. (2020). Moving toward Net-Zero emissions requires new alliances for carbon dioxide removal. One Earth 3, 145-149. doi: 10.1016/j.oneear.2020. 08.002

Fyson, C. L., Baur, S., Gidden, M., and Schleussner, C. F. (2020). Fair-share carbon dioxide removal increases major emitter responsibility. Nat. Clim. Chang. 10, 836-841. doi: 10.1038/s41558-020-0857-2

Geden, O. (2016a). An actionable climate target. Nat. Geosci. 9, 340-342. doi: 10.1038/ngeo2699

Geden, O. (2016b). The Paris agreement and the inherent inconsistency of climate policymaking. WIREs Clim. Change 7, 790-797. doi: 10.1002/wcc.427

Geden, O., and Schenuit, F. (2020). Unconventional Mitigation: Carbon Dioxide Removal as a New Approach in EU Climate Policy. SWP Research Paper 8/2020. Berlin: German Institute for International and Security Affairs.

Geden, O., Scott, V., and Palmer, J. (2018). Integrating carbon dioxide removal into EU climate policy: prospects for a paradigm shift. WIREs Clim. Change 9:e521. doi: $10.1002 /$ wcc. 521

Geels, F. G., Kern, F., Fuchs, G., Hinderer, N., Kungl, G., Mylan, J., et al. (2016). The enactment of socio-technical transition pathways: a reformulated typology and a comparative multi-level analysis of the German and UK low-carbon electricity transitions (1990-2014). Res. Policy 45, 896-913. doi: 10.1016/j.respol.2016.01.015

Geels, F. G., Turnheim, B., Asquith, M., Kern, F., and Kivimaa, P. (2019). Sustainability Transitions: Policy and Practice. Brussels: European Environmental Agency. Available online: https://www.eea.europa.eu/ publications/sustainability-transitions-policy-and-practice (accessed January 24, 2021).

Geels, F. W. (2007). Feelings of discontent and the promise of middle range theory for STS. Sci. Technol. Hum. Values 32, 627-651. doi: $10.1177 / 0162243907303597$

Geels, F. W. (2011). The multi-level perspective on sustainability transitions: responses to seven criticisms. Environ. Innov. Soc. Transit. 1, 24-40. doi: 10.1016/j.eist.2011.02.002

Geels, F. W., and Schot, J. (2007). Typology of sociotechnical transition pathways. Res. Policy 36, 399-417. doi: 10.1016/j.respol.2007.01.003

Geels, F. W., Sovacool, B. K., Schwanen, T., and Sorrell, S. (2017). The socio-technical dynamics of low-carbon transitions. Joule 1, 463-479. doi: 10.1016/j.joule.2017.09.018
German Government (2016). Climate Action Plan 2050: Principles and Goals of the German Government's Climate Policy. Available online at: https://www.bmu. de/fileadmin/Daten_BMU/Pools/Broschueren/klimaschutzplan_2050_en_bf. pdf (accessed January 24, 2021).

Glynn, J., Gargiulo, M., Chiodi, A., Deane, P., Rogan, F., and, Ó Gallachóir, B. (2018). Zero carbon energy system pathways for Ireland consistent with the Paris agreement. Clim. Policy 19, 30-42. doi: 10.1080/14693062.2018.1464893

Government of Sweden (2014). Förordning (2014:21) om geologisk lagring av koldioxid [Decree on geological storage of carbon dioxide, including amendments until 2016:1190]. Stockholm.

Government of Sweden (2016). En klimat- och luftvårdsstrategi för Sverige, del 1, SOU 2016:47 [A climate and clean air strategy for Sweden, part 1, SOU 2016:47]. Stockholm.

Government of Sweden (2017). Klimatlagen, svensk författningssamling 2017:720 [The climate law, swedish statues 2017:720]. Stockholm.

Government of Sweden (2020). Vägen till en klimatpositiv framtid, SOU 2020:4 [The pathway to a climate-positive future, SOU 2020:4]. Stockholm.

Government of Sweden (2021). Regleringsbrev för budgetåret 2021 avseende Statens energimyndighet, Regeringsbeslut II 18 [Public service agreement for the 2021 budget appropriation concerning the Energy Agency, Government decision II 18]. Stockholm.

Hahn, A., Szarka, N., and Thrän, D. (2020). German energy and decarbonization scenarios: "Blind Spots" with respect to biomass-based carbon removal options. Front. Energy Res. 8, 1-15. doi: 10.3389/fenrg.2020.00130

Haikola, S., Hansson, A., and Fridahl, M. (2019). Map-makers and navigators of politicised terrain: expert understandings of epistemological uncertainty in integrated assessment modelling of bioenergy with carbon capture and storage. Futures 114:102472. doi: 10.1016/j.futures.2019.102472

Harrison, E., and Bruce, H. (2019). Socio-Economic Impacts of Large-Scale Afforestation on Rural Communities in the Wairoa District. Waingawa: Beef + Lamb NZ. Available online at: https://beeflambnz.com/sites/default/files/ Wairoa\%20Afforestation_FINAL.pdf (accessed January 24, 2021).

Hess, D. J. (2014). Sustainability transitions: a political coalition perspective. Res. Policy 43, 278-283. doi: 10.1016/j.respol.2013.10.008

Hirschman, A. O. (1977). Passions and the Interests - Political Arguments for Capitalism Before Its: Political Arguments for Capitalism Before Its Triumph. Princeton, NJ: Princeton University Press. doi: 10.1515/9781400848515

Honegger, M., Michaelowa, A., and Roy, J. (2020). Potential implications of carbon dioxide removal for the sustainable development goals. Clim. Policy. 1-21. doi: 10.1080/14693062.2020.1843388. [Epub ahead of print].

IPCC (2018). Global Warming of $1.5^{\circ} \mathrm{C}$. An IPCC Special Report on the Impacts of Global Warming of $1.5^{\circ} \mathrm{C}$ Above Pre-Industrial Levels and Related Global Greenhouse Gas Emission Pathways, in the Context of Strengthening the Global Response to the Threat of Climate Change, Sustainable Development, and Efforts to Eradicate Poverty. Geneva: IPCC.

Irish Government (2020). Climate Action and Low Carbon Development (Amendment) Bill 2020. Available online at: https://assets.gov.ie/90167/ 93bd2ab8-fde8-40ae-b896-38b1f0854321.pdf (accessed January 24, 2021).

Jacobson, R., and Sanchez, D. L. (2019). Opportunities for carbon dioxide removal within the United States Department of Agriculture. Front. Clim. 1:2. doi: $10.3389 /$ fclim.2019.00002

Jänicke, M. (2017). "Germany: innovation and climate leadership," in The European Union in International Climate Change Politics. Still Taking a Lead?, eds R. Wurzel, J. Connelly, and D. Liefferink (London; New York, NY: Routledge), 114-129.

Jasanoff, S. (2005). Designs on Nature: Science and Democracy in Europe and the United States. Princeton, NJ: Princeton University Press. doi: $10.1515 / 9781400837311$

Jordan, A., and Huitema, D. (2014). Innovations in climate policy: the politics of invention, diffusion, and evaluation. Env. Polit. 23, 715-734. doi: 10.1080/09644016.2014.923614

Kingdon, J. W. (1995). Agendas, Alternatives, and Public Policies. 2. ed. New York, NY: Longman.

Klima- Energi-og Forsyningsudvalget Denmark (2020). Non-paper on Carbon Capture and Storage (CCS). By the Netherlands, Norway, Denmark and Sweden. Available online at: https://www.ft.dk/samling/20201/almdel/KEF/ bilag/87/2288136.pdf (accessed January 24, 2020). 
Köhler, J., Geels, F. W., Kern, F., Markard, J., Onsongo, E., Wieczorek, A., et al. (2019). An agenda for sustainability transitions research: state of the art and future directions. Environ. Innov. Soc. Transit. 31, 1-32. doi: 10.1016/j.eist.2019.01.004

Kulovesi, K., and Oberthür, S. (2020). Assessing the EU's 2030 climate and energy policy framework: incremental change toward radical transformation? RECIEL 29, 151-166. doi: 10.1111/reel.12358

Larsen, J., Herndon, W., Grant, M., and Marsters, P. (2019). Capturing Leadership: Policies for the US to Advance Direct Air Capture Technology. New York, NY: Rhodium Group. Available online at: https://rhg.com/wp-content/uploads/ 2019/05/Rhodium_CapturingLeadership_May2019-1.pdf (accessed December 6, 2020).

Lomax, G., Lenton, T. M., Adeosun, A., and Workman, M. (2015). Investing in negative emissions. Nat. Clim. Chang. 5, 498-500. doi: 10.1038/nclimate2627

Lövbrand, E. (2011). Co-producing European climate science and policy: a cautionary note on the making of useful knowledge. Sci. Pub. Pol. 38, 225-236. doi: 10.3152/030234211X12924093660516

Low, S., and Schäfer, S. (2020). Is bio-energy carbon capture and storage (BECCS) feasible? The contested authority of integrated assessment modeling. Energy Res. Soc. Sci. 60:101326. doi: 10.1016/j.erss.2019.101326

Luderer, G., Vrontisi, Z., Bertram, C., Edelenbosch, O. Y., Pietzcker, R. C., Rogelj, J., et al. (2018). Residual fossil CO2 emissions in $1.5-2{ }^{\circ} \mathrm{C}$ pathways. Nat. Clim. Chang 8, 626-633. doi: 10.1038/s41558-018-0198-6

Marshall, J. P. (2016). Disordering fantasies of coal and technology: carbon capture and storage in Australia. Energy Policy 99, 288-298. doi: 10.1016/j.enpol.2016.05.044

Matthews, A. (2019). Accounting for the LULUCF Sector in the EU's 2030 Climate Targets. CAP Reform Blog. Available online at: http://capreform.eu/ accounting-for-the-lulucf-sector-in-the-eus-2030-climate-targets/ (accessed January 24, 2021).

McKnight, D., and Hobbs, M. (2018). "Fighting for coal: public relations and the campaigns against lower carbon pollution policies in Australia," in Carbon Capitalism and Communication. Confronting Climate Crisis, eds B. Brevini and G. Murdock (London: Palgrave Macmillan), 115-29. doi: 10.1007/978-3-319-57876-7_10

McLaren, D. P., Tyfield, D. P., Willis, R., Szersynksi, B., and Markusson, N. O. (2019). Beyond "Net-Zero": a case for separate targets for emissions reduction and negative emissions. Front. Clim. 1:4. doi: 10.3389/fclim.2019.00004

McMullin, B., Jones, M. B., Price, P. R., McGeever, A., and Rice, P. (2020). Investigating the Potential for Negative Emissions Technologies (NETs) in Ireland. Report 354. Wexford: Environmental Protection Agency Ireland. Available online at: https://www.epa.ie/pubs/reports/research/climate/Research_Report_ 354.pdf (accessed January 24, 2021).

McMullin, B., Price, P., Jones, M. B., and McGeever, A. H. (2019). Assessing negative carbon dioxide emissions from the perspective of a national "fair share" of the remaining global carbon budget. Mitigat. Adapt. Strat. Global Change 25, 579-602. doi: 10.1007/s11027-019-09881-6

McMullin, B., and Price, P. R. (2020). Synthesis of Literature and Preliminary Modelling Relevant to Society-wide Scenarios for Effective Climate Change Mitigation in Ireland. Report 352. Wexford: Environmental Protection Agency Ireland. Available online at: http://www.epa.ie/pubs/reports/research/climate/ Research_Report_352.pdf (accessed January 24, 2021).

Merton, R. (1936). The unanticipated consequences of purposive social action. Am. Sociol. Rev. 1, 894-904. doi: 10.2307/2084615

Ministry for Primary Industries, New Zealand (2020). About the One Billion Trees Programme. Available online at: https:/www.mpi.govt.nz/forestry/fundingtree-planting-research/one-billion-trees-programme/about-the-one-billiontrees-programme/ (accessed January 24, 2021).

Ministry for the Environment, New Zealand (2019). Zero Carbon Bill Economic Analysis: A Synthesis of Economic Impacts. Available online at: https://www. mfe.govt.nz/sites/default/files/media/Climate\%20Change/Zero-Carbon-BillEconomic-Analysis-Report-FINAL.pdf (accessed January 24, 2021).

Minx, J. C., Lamb, W. F., Callaghan, M. W., Bornmann, L., and Fuss, S. (2017). Fast growing research on negative emissions. Environ. Res. Lett. 12:35007. doi: 10.1088/1748-9326/aa5ee5

Minx, J. C., Lamb, W. F., Callaghan, M. W., Fuss, S., Hilaire, J., Creutzig, F., et al. (2018). Negative emissions-Part 1: Research landscape and synthesis. Environ. Res. Lett. 13:63001. doi: 10.1088/1748-9326/aabf9b
Möllersten, K. (2002). Opportunities for CO2 Reductions and CO2-LeanEnergy Systems in Pulp and Paper Mills. Doctoral thesis. KTH Royal Institute of Technology, Stockholm.

Morrow, D. R. (2014). Ethical aspects of the mitigation obstruction argument against climate engineering research. Phil. Trans. R. Soc. A 372:20140062. doi: $10.1098 /$ rsta.2014.0062

Morrow, D. R., Thompson, M. S., Anderson, A., Batres, M., Buck, H. J., Dooley, K., et al. (2020). Principles for thinking about carbon dioxide removal in just climate policy. One Earth 3, 150-153. doi: 10.1016/j.oneear.2020. 07.015

Nemet, G. F., Callaghan, M. W., Creutzig, F., Fuss, S., Hartmann, J., Hilaire, J., et al. (2018). Negative emissions-Part 3: Innovation and upscaling. Environ. Res. Lett. 13:63003. doi: 10.1088/1748-9326/aabff4

Norsk Biokullnettverk (2020). Mandat for Norsk Biokullnettverk. Available online at: https://www.biokull.info/mandat (accessed January 24, 2021).

Obersteiner, M., Azar, C., Kauppi, P., Möllersten, K., Moreira, J., Nilsson, S., et al. (2001). Managing climate risk. Science 294, 786-787. doi: 10.1126 /science.294.5543.786b

Parliamentary Comissioner for the Environment, New Zealand (2019). Farms, Forests and Fossil Fuels: The Next Great Landscape Transformation? Available online at: https://www.pce.parliament.nz/media/196523/report-farms-forestsand-fossil-fuels.pdf (accessed January 24, 2021).

Pauw, P., Mbeva, K., and van Asselt, H. (2019). Subtle differentiation of countries' responsibilities under the Paris agreement. Palgrave Commun. 5:86. doi: 10.1057/s41599-019-0298-6

Peters, G. P., and Geden, O. (2017). Catalysing a political shift from low to negative carbon. Nat. Clim. Chang. 7, 619-621. doi: 10.1038/nclimate3369

Pozo, C., Galán-Martín, Á., Reiner, D. M., Mac Dowell, N., and Guillén-Gosálbez, G. (2020). Equity in allocating carbon dioxide removal quotas. Nat. Clim. Chang. 10, 640-646. doi: 10.1038/s41558-020-0802-4

Productivity Commission, New Zealand (2018). Low-Emissions Economy: Final Report. Available online at: https://www.productivity.govt.nz/ assets/Documents/4e01d69a83/Productivity-Commission_Low-emissionseconomy_Final-Report.pdf (accessed January 24, 2021).

Prognos, Öko-Institut, Wuppertal-Institut (2020). Towards a Climate-Neutral Germany: Three Steps for Achieving Climate Neutrality by 2050 and an Intermediate Target of-65\% in 2030 as Part of the EU Green Deal: Executive Summary Conducted for Agora Energiewende, Agora Verkehrswende and Stiftung Klimaneutralität. Available online at: https://static.agoraenergiewende.de/fileadmin2/Projekte/2020/2020_10_KNDE/A-EW_193_ KNDE_Executive-Summary_EN_WEB_V111.pdf (accessed January 24, 2021).

Raum, S., and Potter, C. (2015). Forestry paradigms and policy change: the evolution of forestry policy in Britain in relation to the ecosystem approach. Land Use Policy 49, 462-470. doi: 10.1016/j.landusepol.2015.08.021

Rayner, T., and Jordan, A. (2016). "Climate change policy in the European union," in Oxford Research Encyclopedia of Climate Science. 1-25. doi: 10.1093/acrefore/9780190228620.013.47

Rickels, W., Proelß, A., Geden, O., Burhenne, J., and Fridahl, M. (2020). The Future of (Negative) Emissions Trading in the European Union. Kiel Working Paper No. 2164. Kiel: Kiel Institute for the World Economy.

Rimmer, D. (2016). Breakdown of governance: a critical analysis of New Zealand's climate change response. PhD thesis. Massey University, Manawatu, New Zealand.

Robiou Du Pont, Y., Jeffery, M. L., Gütschow, J., Rogelj, J., Christoff, P., and Meinshausen, M. (2017). Equitable mitigation to achieve the Paris agreement goals. Nat. Clim. Chang. 7, 38-43. doi: 10.1038/nclimate3186

Rodriguez, E., Lefvert, A., Fridahl, M., Grönkvist, S., Haikola, S., and Hansson, A. (2020). Tensions in the energy transition: Swedish and Finnish company perspectives on bioenergy with carbon capture and storage. J. Clean. Prod. 2020:124527. doi: 10.1016/j.jclepro.2020.124527

Royal Society and Royal Academy of Engineering (2018). Report: Greenhouse Gas Removal. Available online at: https://royalsociety.org/-/media/policy/projects/ greenhouse-gas-removal/royal- society-greenhouse-gas-removal-report- 2018. pdf (accessed January 24, 2021).

Sanchez, D. L., Amador, G., Funk, J., and Mach, K. J. (2018). Federal research, development, and demonstration priorities for carbon dioxide removal in the United States. Environ. Res. Lett. 13:15005. doi: 10.1088/1748-9326/ aaa08f 
Shue, H. (2018). Mitigation gambles: uncertainty, urgency and the last gamble possible. Phil. Trans. R. Soc. A 376:20170105. doi: 10.1098/rsta. 2017.0105

Smith, A., and Raven, R. (2012). What is protective space? Reconsidering niches in transitions to sustainability. Res. Policy 41, 1025-1036. doi: 10.1016/j.respol.2011.12.012

Smith, A., Stirling, A., and Berkhout, F. (2005). The governance of sustainable socio-technical transitions. Res. Policy 34, 1491-1510. doi: 10.1016/j.respol.2005.07.005

Smith, A., Voß, J.-P., and Grin, J. (2010). Innovation studies and sustainability transitions: the allure of the multi-level perspective and its challenges. Res. Policy 39, 435-448. doi: 10.1016/j.respol.2010.01.023

Smith, K. B. (2002). Typologies, taxonomies, and the benefits of policy classification. Policy Stud. J. 30, 379-395. doi: 10.1111/j.1541-0072. 2002.tb02153.x

Smith, P., Nkem, J., Calvin, K., Campbell, F., Cherubini, G., Grassi, V., et al. (2019). "Interlinkages between desertification, land degradation, food security and GHG fluxes: synergies, trade-offs and integrated response options," in Climate Change and Land: An IPCC Special Report on Climate Change, Desertification, Land Degradation, Sustainable land Management, Food Security, and Greenhouse Gas Fluxes in Terrestrial Ecosystems (Geneva: IPCC), 551-672.

Steinberger, P. J. (1980). Typologies of public policy: meaning construction and the policy process. Soc. Sci. Q. 61, 185-192.

Szulecki, K., Fischer, S., Gullberg, A. T., and Sartor, O. (2016). Shaping the 'Energy Union': between national positions and governance innovation in EU energy and climate policy. Clim. Policy 16, 548-567. doi: 10.1080/14693062.2015.1135100

The White House (2021). Executive Order on tackling the Climate Crisis at Home and Abroad. Available online at: https://www.whitehouse.gov/briefing-room/ presidential-actions/2021/01/27/executive-order-on-tackling-the-climatecrisis-at-home-and-abroad/ (accessed January 24, 2021).

Torvanger, A. (2019). Governance of bioenergy with carbon capture and storage (BECCS): accounting, rewarding, and the Paris agreement. Clim. Policy 19, 329-341. doi: 10.1080/14693062.2018.1509044

UK Government (2017). The Clean Growth Strategy: Leading the Way to a Low Carbon Future. Available online at: https://www.gov.uk/guidance/createwoodland-overview (accessed January 24, 2021).

UK Government (2018). Create Woodland: Overview. Available online at: https:// www.gov.uk/guidance/create-woodland-overview (accessed January 24, 2021).

UK Government (2019). The Climate Change Act 2008 (2050 Target Amendment) Order, 2019. Available online at: https://www.legislation.gov.uk/ukdsi/2019/ 9780111187654 (accessed January 24, 2021).

UK Government (2020a). Budget 2020. Policy Paper. Available online at: https:// www.gov.uk/government/publications/budget-2020-documents/budget-2020 (accessed January 24, 2021).

UK Government (2020b). The Ten Point Plan for a Green Industrial Revolution: Building Back Better, Supporting Green Jobs, and Accelerating Our Path to Net Zero. Available online at: https://assets.publishing.service.gov.uk/government/ uploads/system/uploads/attachment_data/file/936567/10_POINT_PLAN_ BOOKLET.pdf (accessed January 24, 2021).

Umweltbundesamt (2020). Abschätzung der Treibhausgasminderungswirkung des Klimaschutzprogramms 2030 der Bundesregierung. Available online at: https://www.umweltbundesamt.de/publikationen/abschaetzung-dertreibhausgasminderungswirkung-des (accessed January 24, 2021).
United Nations Environmental Program (2017). The Emissions Gap Report 2017: A UN Environment Synthesis Report. Nairobi: United Nations Environmental Program.

van Sluisveld, M. A., Hof, A. F., Carrara, S., Geels, F. W., Nilsson, M., Rogge, K., et al. (2020). Aligning integrated assessment modelling with socio-technical transition insights: An application to low-carbon energy scenario analysis in Europe. Technol. Forecast. Soc. Change 151:119177. doi: 10.1016/j.techfore.2017.10.024

Victor, D. G., Geels, F. G., and Sharpe, S. (2019). Accelerating the Low Carbon Transition. The Case for Stronger, More Targeted and Coordinated International Action. Brookings Institution. Available online at: https://www.brookings.edu/ wp-content/uploads/2019/12/Coordinatedactionreport.pdf (accessed January 24, 2021).

Vivid Economics (2019). Greenhouse Gas Removal Policy Options. Available online at: https://assets.publishing.service.gov.uk/government/uploads/system/ uploads/attachment_data/file/833145/Greenhouse_Report_Gas_Removal_ policy_options.pdf (accessed January 24, 2021).

vonHedemann, N., Wurtzebach, Z., Timberlake, T. J., Sinkular, E., and Schultz, C. A. (2020). Forest policy and management approaches for carbon dioxide removal. Interface Focus 10:20200001. doi: 10.1098/rsfs.20 20.0001

VW (2020). In Depth: Audi and Climeworks Store CO2 From the Atmosphere Underground. Available online at: https://www.volkswagenag.com/en/news/ 2020/09/audi_climeworks.html (accessed January 24, 2021).

Waller, L., Rayner, T., Chilvers, J., Gough, C. A., Lorenzoni, I., Jordan, A., et al. (2020). Contested framings of greenhouse gas removal and its feasibility: Social and political dimensions. WIREs Clim. Change 11:e649. doi: 10.1002/ wcc. 649

Workman, M., Dooley, K., Lomax, G., Maltby, J., and Darch, G. (2020). Decision making in contexts of deep uncertainty - an alternative approach for longterm climate policy. Environ. Sci. Policy 103, 77-84. doi: 10.1016/j.envsci.2019. 10.002

Woroniecki, S., Wendo, H., Brink, E., Islar, M., Krause, T., Vargas, A. M., et al. (2020). Nature unsettled: How knowledge and power shape 'naturebased' approaches to societal challenges. Glob. Environ. Change 65:102132. doi: 10.1016/j.gloenvcha.2020.102132

Wreford, A., Bayne, K., Edwards, P., and Renwick, A. (2019). Enabling a transformation to a bioeconomy in New Zealand. Environ. Innov. Soc. Transit. 31, 184-199. doi: 10.1016/j.eist.2018.11.005

Disclaimer: The views expressed in this paper do not necessarily represent the views of their funders or the authors' host institutions.

Conflict of Interest: The authors declare that the research was conducted in the absence of any commercial or financial relationships that could be construed as a potential conflict of interest.

Copyright (C) 2021 Schenuit, Colvin, Fridahl, McMullin, Reisinger, Sanchez, Smith, Torvanger, Wreford and Geden. This is an open-access article distributed under the terms of the Creative Commons Attribution License (CC BY). The use, distribution or reproduction in other forums is permitted, provided the original author(s) and the copyright owner(s) are credited and that the original publication in this journal is cited, in accordance with accepted academic practice. No use, distribution or reproduction is permitted which does not comply with these terms. 